\title{
Microbiological Decontamination of Mycotoxins: Opportunities and Limitations
}

\author{
Małgorzata Piotrowska
}

check for updates

Citation: Piotrowska, M. Microbiological Decontamination of Mycotoxins: Opportunities and Limitations. Toxins 2021, 13, 819. https://doi.org/10.3390/ toxins13110819

Received: 26 October 2021 Accepted: 18 November 2021 Published: 19 November 2021

Publisher's Note: MDPI stays neutral with regard to jurisdictional claims in published maps and institutional affiliations.

Copyright: (C) 2021 by the author. Licensee MDPI, Basel, Switzerland. This article is an open access article distributed under the terms and conditions of the Creative Commons Attribution (CC BY) license (https:// creativecommons.org/licenses/by/ $4.0 /)$.
Faculty of Biotechnology and Food Sciences, Institute of Fermentation Technology and Microbiology, Lodz University of Technology, Wólczańska 171/173, 90-530 Lodz, Poland; malgorzata.piotrowska@p.lodz.pl

\begin{abstract}
The contamination of food and feeds with mycotoxins poses a global health risk to humans and animals, with major economic consequences. Good agricultural and manufacturing practices can help control mycotoxin contamination. Since these actions are not always effective, several methods of decontamination have also been developed, including physical, chemical, and biological methods. Biological decontamination using microorganisms has revealed new opportunities. However, these biological methods require legal regulations and more research before they can be used in food production. Currently, only selected biological methods are acceptable for the decontamination of feed. This review discusses the literature on the use of microorganisms to remove mycotoxins and presents their possible mechanisms of action. Special attention is given to Saccharomyces cerevisiae yeast and lactic acid bacteria, and the use of yeast cell wall derivatives.
\end{abstract}

Keywords: mycotoxins; decontamination; adsorption; detoxification; microorganisms; lactic acid bacteria; yeasts

Key Contribution: The use of microorganisms or their enzymes to detoxify mycotoxins generates new possibilities in food and feed production. Lactic acid bacteria and certain species of yeast able to decontaminate mycotoxins could obtain consumer acceptance for use in the production of fermented foods.

\section{Introduction}

Mycotoxins are secondary metabolites of fungi that contaminate both plant raw materials and products of plant and animal origin. They can be produced at any stage of the food chain, mainly by fungi belonging to the genera Aspergillus, Penicillium, Fusarium, Byssochlamys, or Alternaria. Currently, more than 400 compounds are identified as mycotoxins. Most scientific attention has been focused on only a few, due to their frequency and toxic properties. The most important mycotoxins are aflatoxins (AFs), ochratoxin A (OTA), patulin (PAT), citrinin (CIT), Fusarium toxins represented by fumonisins (FUM), deoxynivalenol (DON) and their derivatives, zearalenone (ZEN), T-2 and HT-2 toxins (T-2, HT-2), Alternaria toxins, such as alternariol (AOH), alternariol methyl ether (AME), tenuazonic acid (TeA), and Claviceps ergot alkaloids [1,2].

The main source of human exposure to mycotoxins is food, including not only contaminated food products of plant origin (the primary route), but also contaminated animal tissues (meat, milk, and eggs) derived from animals fed with contaminated fodder. Prolonged exposure to small doses of mycotoxins causes poisoning of various forms, called mycotoxicosis, which may be acute or chronic. Humans and animals are exposed to various types of mycotoxins simultaneously, which may result in antagonistic, additive, or synergistic effects [3]. Mycotoxins have numerous effects on human and animal bodies, causing liver and kidney damage, as well as interfering with the functioning of the digestive tract and the immune system. They may exhibit carcinogenic, mutagenic, cytotoxic, teratogenic, neurotoxic, or estrogenic properties [2]. 
To protect public health in the European Union (EU), the maximum levels of the most toxicologically important mycotoxins permitted in foodstuffs have been established based on the opinions of the European Food Safety Authority (EFSA). EU Regulation 1881/2006 and its amendments (1126/2007, 105/2010, 165/2010, 594/2012 1058/2012, 2015/1137, and 2019/1901) established the maximum acceptable limits for AFs (in nuts, dried fruits, cereals and cereal products, spices, and milk), ochratoxin A (in cereals and cereal products, dried fruits, coffee, grape juice and wine, spices, licorice), patulin (in fruit juices, spirit drinks, cider), fumonisins, deoxynivalenol, zearalenone (in cereals and cereal products, maize and maize-based products, pasta, bread), and citrinin (in food supplements based on rice fermented with Monascus purpureus) [4-11]. Similar regulations, though not covering such a wide range of mycotoxins and product categories, are in force in the USA, Canada, Australia, Japan, China, and other countries, as well as in Codex Alimentarius standards. Maximum acceptable limits also apply to feed-e.g., in EU regulations such as Commission Recommendation 2006/576 [12].

Most review publications on the scale of contamination cite Food and Agriculture Organization of the United Nations (FAO) data from 25 years ago that "up to $25 \%$ of world food crops are significantly contaminated with mycotoxins" [13]. According to more recent data published by Eskola et al. [14], the number of tested samples that exceed acceptable mycotoxin levels in the European Union (EU) are in line with the FAO estimate.

The scale of mycotoxin contamination in foodstuffs analyzed during official food control is reflected in the number of notifications issued by the Rapid Alert System for Food and Feed (RASFF), which is a platform for exchanging information about foods and feeds that may pose a hazard to consumers in Europe. In recent years (since 2015), the RASFF system has registered over 500 notifications of excessive mycotoxin levels in food per year (Figure 1). In 2021, in the period before September, there were 294 notifications, including $16 \%$ alert and $8 \%$ information notifications. Most notifications were issued by border control $(76 \%)$. Nuts, nut products, and seeds were the main product categories exposed to contamination $(62 \%)$.

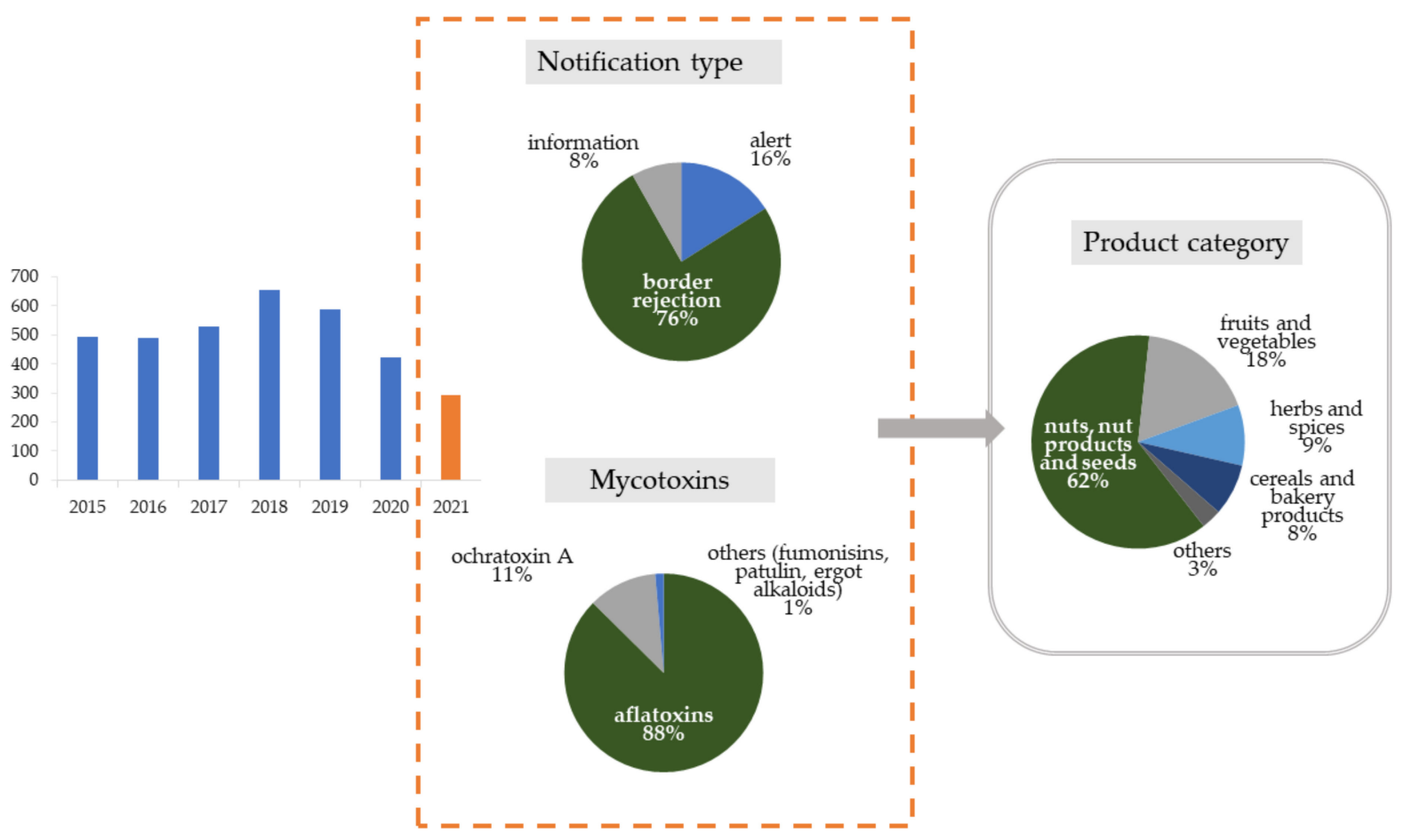

Figure 1. RASFF notifications of excessive levels of mycotoxins from 2015 to 2021. Detailed data on the type of notification, mycotoxins, and products category relate to 2021. 
The scale of the problem appears even greater when we consider levels of mycotoxins in plant materials and food products that are above the limits of detection (LODs) by analytical methods. Not all collected data are published and disseminated by the FAO, World Health Organization (WHO), or EFSA [14]. However, according to Lee and Ryu, $61 \%$ of unprocessed food-grade cereals tested worldwide between 2006 and 2016 were contaminated with fumonisins. The incidence of contamination varied from $39 \%$ in Europe to $95 \%$ in America [15]. The most up-to-date reports on feed contamination are provided by Biomin (Austria). According to their data for the third quarter of 2020 to the second quarter of 2021, the proportions of feed contaminated with mycotoxins were as follows: OTA-9\%, T-2-11\%, Afs-14\%, ZEN-49\%, FUM-49\%, DON-54\%. It should be emphasized that $55 \%$ of the feeds were contaminated with more than one mycotoxin, which may increase their toxic effects [16]. The data from Europe are the most complete. However, this information only includes mycotoxins covered by EU regulations-i.e., AFs, OTA, PAT, ZEA, DON, and FUM. The data do not take into account other toxic metabolites, such as Alternaria toxins and sterigmatocystin, or masked mycotoxins not detected by routine methods [17].

In addition to its negative impact on human and animal health, mycotoxin contamination has global economic consequences. For this reason, minimizing mycotoxin contamination has become a priority for scientists and organizations including the WHO, FAO, and EFSA.

\section{Mycotoxin Control Strategies}

There are two strategies for the control of mycotoxin contamination (Figure 2): prevention strategies (white boxes) and decontamination strategies (gray boxes). These strategies can be employed at different stages of the production process, often classified as pre-harvest and post-harvest (above and under the dotted line, respectively).

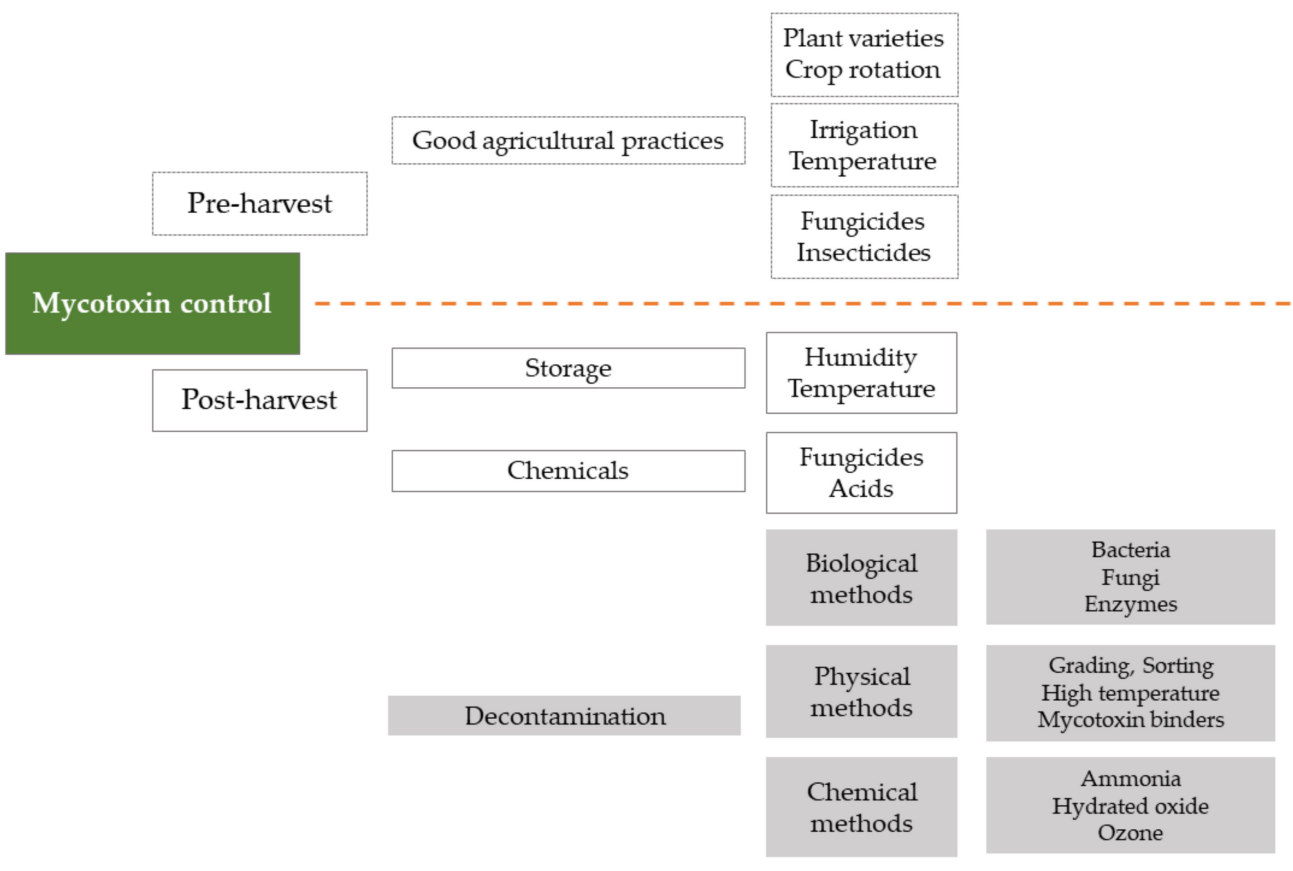

Figure 2. Mycotoxin control strategies.

Pre-harvest actions include: the selection of varieties or hybrids resistant to fungal infections and insect pests; minimizing the exposure of plants to stress (drought); careful use of insecticides and herbicides; crop rotation; timely harvest; good soil management to remove, destroy, or bury infected harvest residues. Guidelines for the application of appropriate preventive measures are presented in EU Regulation 1881/2006 and EU 
Commission Recommendation 583/2006 (on the prevention and reduction of Fusarium toxins in cereals and cereal products) [11,18].

Post-harvest methods to prevent the growth of toxicogenic fungi include storage of crops under conditions of appropriate humidity and temperature, or the use of chemical fungicides. If, despite these methods, the products are contaminated with mycotoxins, treatments may be applied to reduce levels of mycotoxins. These include traditional and innovative physical methods (e.g., sorting, thermal treatment, UV radiation, cold plasma, electron beam irradiation, pulsed electric field, adsorbents), as well as chemical methods (addition of oxidants such as hydrogen peroxide, sulfur dioxide, sodium hypochlorite, ozone, or ammonia) [19-21].

However, some of these methods are not applicable in practice, mainly due to the risk of creating toxic residues or affecting the nutritional value and organoleptic properties of the purified products [20]. Moreover, there are currently no legal regulations regarding decontamination of food. According to Regulation 1881/2006, foodstuffs that do not comply with accepted maximum levels of toxins should not be used as food ingredients, nor mixed with other foodstuffs, and should not be deliberately detoxified using chemical treatments. The presence of contaminants in food must be reduced as much as possible by Good Manufacturing Practice (GMP), Good Agriculture Practices (GAP), and the application of Hazard Analysis and Critical Points (HACCP). Sorting or other physical treatment methods make it possible to reduce the AF content in groundnuts, nuts, dried fruit, and cereals [11]. The regulations do not mention biological methods of decontamination.

\section{Background}

The subject of reducing the number of mycotoxins in food and feed is of great interest to scientists. Searching the Web of Science Core Collection for the terms ("mycotoxins" OR "mycotoxin") AND ("degradation" OR "biodegradation" OR "detoxification" OR "biodetoxification" OR "binding" OR "control" OR "adsorption" OR "elimination" OR "decreasing" OR "minimizing" OR "inactivation" OR "mitigation" OR "transformation" OR "biotransformation" OR "decontamination") yields 8854 publications from 1990 to the present day. The majority of these publications are original articles. The number of review articles is growing, but they still constitute only $9 \%$ of the total number of articles (Figure 3).

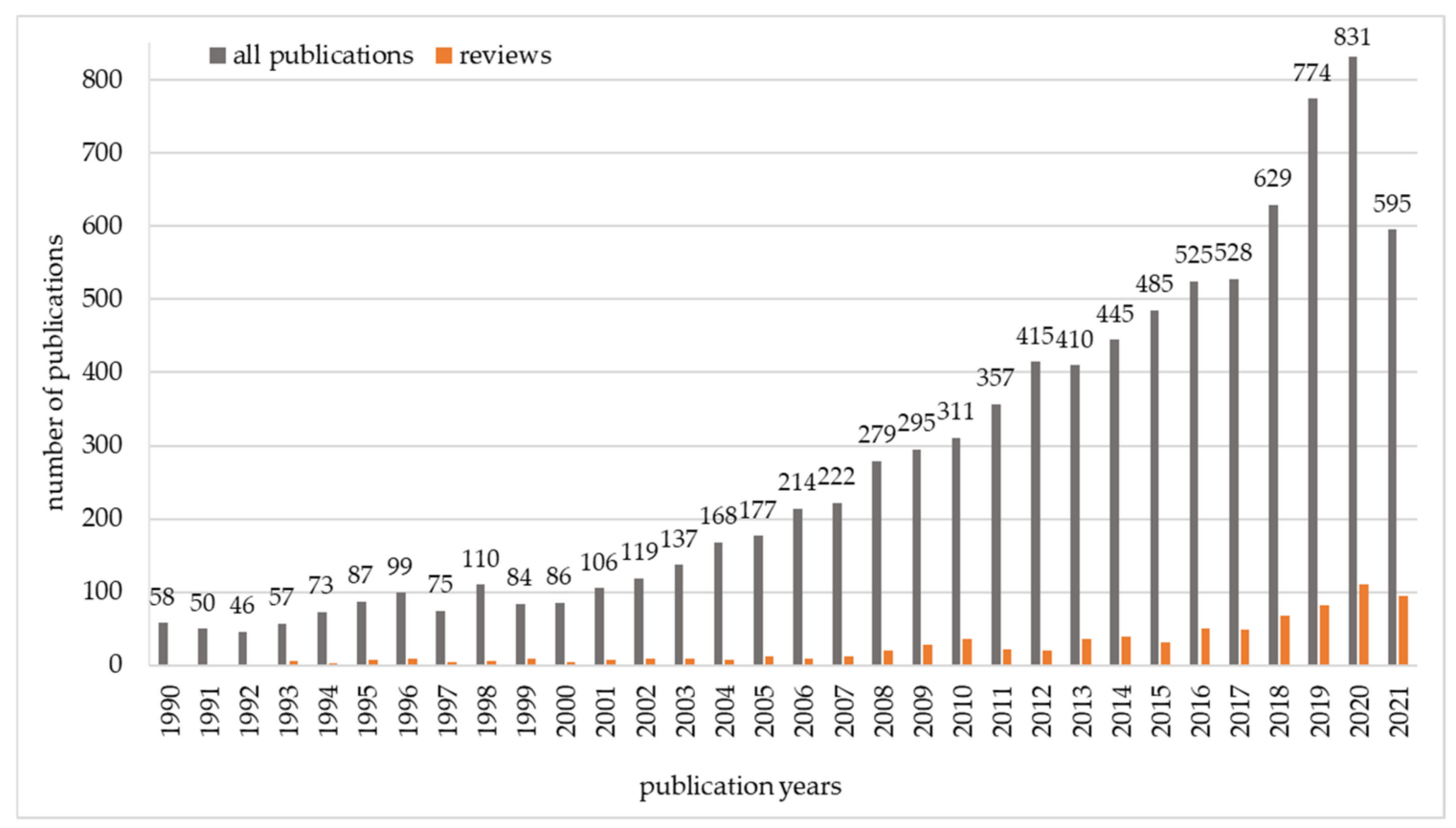

Figure 3. Number of publications on mycotoxin biodegradation from 1990 to 2021, based on the results of searching the Web of Science Core Collection (total $=8854$ ). 
A preliminary review of the literature published in the years 1990-2021, using the terms "(bio)degradation", "(bio)detoxification", "(bio)transformation", "decontamination", "binding", "control", "adsorption", "elimination", "decreasing", "minimizing", "inactivation", and "mitigation" in combination with "mycotoxins", identified almost 9000 articles, book chapters, and conference papers in scientific databases (Scopus, Science Direct, Web of Science). The search terms were included in the titles, keywords, and abstracts. Articles published in languages other than English were excluded, as were articles that were unavailable as full texts, and conference papers that had not been peer-reviewed.

In total, 136 scientific papers were selected for discussion in this literature review, of which $66 \%$ were published in the years $2010-2021,28 \%$ in $2000-2009,4 \%$ in $1990-2000$, and $1 \%$ before the 1990s. Thirteen law regulations and one web page were also reviewed. The selected publications were used to answer the following questions: (1) What is the level of research interest in this topic, in terms of the number of publications? (2) What is the current situation, in terms of mycotoxin contamination of food and feed products? (3) What trends can be identified in research on mycotoxin decontamination? (4) Which microorganisms show the greatest potential for use as decontaminants? (5) What are their mechanisms of decontamination? (6) Which methods can be applied in practice?

\section{Microbiological Methods of Decontamination}

The idea of using microorganisms to remove mycotoxins appeared as early as the 1960s. Ciegler et al. [22] reviewed microorganisms in terms of their ability to degrade aflatoxins (AFs). They found that some molds, including Aspergillus niger, Aspergillus parasiticus, Aspergillus terreus, Aspergillus luchuensis, Penicillium reistrickii, as well as Flavobacterium aurantiacum (now Rhodococcus corynebacterioides) bacteria are able to transform AFs into a new undefined product. In the following years, it was shown that other microorganisms also exhibit this feature. These include bacteria such as F. aurantiacum [23-26], Rhodococcus erythropolis, and Mycobacterium fluoranthenivorans [27], Acinetobacter calcoaceticus [28], Bacillus megaterium [29], Oenococcus oeni [30], Bifidobacterium sp. [31,32], Lactobacillus sp. [31-40], yeasts such as Saccharomyces cerevisiae, Kluyveromyces marxianus, Rhodotorula rubra, Kloeckera apiculata, Candida famata [41-46], and filamentous fungi from Aspergillus, Penicillium, Rhizopus, and Aureobasidium genera [47-51].

Given the limitations of physical and chemical methods of decontamination, biological methods using microorganisms or their enzymes are becoming the focus of more research. Approximately $50 \%$ of the publications presented in Figure 3 concerned biological methods of decontamination. Until 2010, most publications focused on the search for microorganisms capable of removing aflatoxin B1 (AFB1), and to a lesser extent other mycotoxins (OTA, patulin, and Fusarium mycotoxins). The aim was often to reduce the number of mycotoxins under model conditions, in a buffer or microbiological medium, sometimes related to food or feed $[30,33,41,48,49]$. Some authors described possible decontamination mechanisms, such as enzymatic biotransformation $[26,47,50,51]$ or adsorption to microbial cells $[23,34,36,40,41,44,48]$.

After 2010, more advanced research attempted to explain the mechanisms of action by microorganisms. Table 1 presents the subjects of reports from the last 10 years, showing the types of microorganisms, the types of mycotoxins, and the proposed decontamination mechanisms.

As can be seen in Table 1, most studies have focused on the use of bacteria for mycotoxin decontamination. In total, 33 species have been studied from Alcaligenes, Bacillus, Brevibacterium, Cupriavidus, Devosia, Escherichia, Enterobacter, Lysinibacter, Lysinibacillus, Pediococcus, Pseudomonas, Rhodococcus, and Streptomyces, as well as lactic acid bacteria. Three consortia of bacteria isolated from soil, compost, and kefir grains were also examined. Fewer studies concerned fungi, most of which focused on the use of yeasts for the decontamination of mycotoxins. 
Table 1. Reports concerning the microbial decontamination of mycotoxins in the years 2011-2021.

\begin{tabular}{|c|c|c|c|}
\hline Microorganisms & Targeted Mycotoxins & Mechanism & References \\
\hline Alcaligenes faecalis & OTA Bacteria & Biodegradation to $\mathrm{OT} \alpha$ & [52] \\
\hline Bacillus amyloliquefaciens & OTA & $\begin{array}{l}\text { Biodegradation to OT } \alpha \text { due to } \\
\text { carboxypeptidase activity }\end{array}$ & [53] \\
\hline Bacillus amyloliquefaciens & ZEN & Adsorption to bacterial cells & [54] \\
\hline Bacillus licheniformis & ZEN & Adsorption to bacterial cells & [55] \\
\hline Bacillus megaterium & OTA & Adsorption to bacterial cells & [56] \\
\hline Bacillus pumilus & ZEN & Biotransformation due to esterase activity & [57] \\
\hline Bacillus subtilis & $\mathrm{AFB}_{1}$ & $\begin{array}{l}\text { Biotransformation into less toxic products due to } \\
\text { laccase activity }\end{array}$ & [58] \\
\hline Bacillus subtilis & DON & NA & [59] \\
\hline Bacillus subtilis & OTA & Adsorption to bacterial cells & [60] \\
\hline Bacillus subtilis & ZEN; $17-\beta$-estradiol & $\begin{array}{l}\text { Biotransformation into ZEN-14-phosphate and } \\
\text { 17- } \beta \text {-estradiol-3-phosphate }\end{array}$ & [61] \\
\hline Bacillus velezensis & AFB1 & Biotransformation into less cytotoxic products & [62] \\
\hline Brevibacterium casei, B. linens, B. iodinum & OTA & Biodegradation to OT $\alpha$ & [63] \\
\hline $\begin{array}{c}\text { Cupriavidus numazuensis; } \text { C. oxalaticus, } C \text {. basilensis, } C \text {. } \\
\text { metalliduriens }\end{array}$ & OTA, AFB1, ZEN, T-2 & $\begin{array}{l}\text { Biotransformation into undefined products with } \\
\text { lower toxicity }\end{array}$ & {$[64,65]$} \\
\hline Devosia insulae & DON & Biotransformation into 3-keto-DON & [66] \\
\hline Escherichia coli & $\mathrm{AFB}_{1}$ & $\begin{array}{l}\text { Biotransformation into less toxic products } \\
\left(\mathrm{C}_{16} \mathrm{H}_{14} \mathrm{O}_{5} \text { and other metabolites }\right)\end{array}$ & [67] \\
\hline Enterobacter cloaceae subsp. dissolvens & PAT & Enzymatic biotransformation into E-ascladiol & [68] \\
\hline Gluconobacter oxydans & AFB1, OTA, CIT, PAT & $\begin{array}{c}\text { Physical binding to bacterial cell wall proteins and } \\
\text { polysaccharides }\end{array}$ & [69] \\
\hline $\begin{array}{l}\text { Lactiplantibacillus plantarum }^{1} \text {, } \\
\text { Levilactobacillus brevis }^{1}, \\
\text { Fructilactobacillus sanfranciscensis }{ }^{1}\end{array}$ & OTA & Adsorption into the bacterial cell wall & [70] \\
\hline Lactiplantibacillus plantarum $^{1}$ & PAT & Biotransformation into E-ascladiol & [71] \\
\hline Lacticaseibacillus casei ${ }^{1}$ & PAT & $\begin{array}{l}\text { Simultaneous partial biotransformation into an } \\
\text { undefined product and adsorption into the bacterial } \\
\text { cell wall }\end{array}$ & [72] \\
\hline Lactiplantibacillus plantarum $^{1}$ & ZEN & NA & [73] \\
\hline Lactiplantibacillus plantarum $^{1}$ & ZEN & Biotransformation due to esterase activity & [74] \\
\hline Lysinibacillus sp. & ZEN & Enzymatic biotransformation & [75] \\
\hline Lysobacter sp. & OTA & Biodegradation to OT $\alpha$ & [76] \\
\hline Nocardioides & DON & $\begin{array}{l}\text { Biotransformation into 3-keto-DON and 3-epi-DON } \\
\text { as intermediate products }\end{array}$ & [77] \\
\hline Pediococcus parvulus & OTA & Biodegradation to OT $\alpha$ & [78] \\
\hline Pelagibacterium halotolerans & DON & $\begin{array}{l}\text { Biotransformation into less-toxic 3-keto-DON by } \\
\text { oxidation of the C3 hydroxyl group }\end{array}$ & [79] \\
\hline Pseudomonas geniculata & $\mathrm{AFB}_{1}$ & Non-enzymatic transformation into $\mathrm{C}_{17} \mathrm{H}_{14} \mathrm{O}_{7}$ & [80] \\
\hline Rhodococcus pyridinivorans & $\mathrm{AFB}_{1}$ & NA & [81] \\
\hline Rhodococcus pyridinivorans & ZEN & $\begin{array}{l}\text { Biotransformation into non-estrogenic } \\
\text { undefined products }\end{array}$ & [82] \\
\hline $\begin{array}{c}\text { Rhodococcus erythropolis, } R \text {. rhodochrous, } \\
\text { R. pyridinivoran }\end{array}$ & $\mathrm{AFB}_{1}, \mathrm{~T}-2$ & $\begin{array}{l}\text { Biotransformation into undefined non } \\
\text { genotoxic products }\end{array}$ & [83] \\
\hline Sphingomonadales family & $\mathrm{FB}_{1}$ & $\begin{array}{l}\text { Biodegradation into an undefined hydrolyzed } \\
\text { product due to carboxyesterase activity }\end{array}$ & [84] \\
\hline Streptomyces spp. & $\mathrm{AFB}_{1}$ & $\begin{array}{l}\text { Biotransformation into undefined less } \\
\text { genotoxic products }\end{array}$ & [85] \\
\hline $\begin{array}{l}\text { Bacterial consortium isolated from soil } \\
\text { (Methylophilus; Hyphomicrobium; Ancylobacter; } \\
\text { Pseudomonas; Prosthecomicrobium; Taonella; Bosea, and } \\
\text { other genera }\end{array}$ & DON & Biotransformation into 3-keto-DON & [86] \\
\hline $\begin{array}{c}\text { Microorganisms from Kefir grains } \\
\text { (Lentilactobacillus kefiri }{ }^{1}, \text { Kazachstania servazzii }{ }^{2} \text { and } \\
\text { Acetobacter syzygii) }\end{array}$ & $\mathrm{AFB}_{1}, \mathrm{ZEN}, \mathrm{OTA}$ & Adsorption & [87] \\
\hline $\begin{array}{l}\text { Bacterial consortium consists of Geobacillus, } \\
\text { Tepidimicrobium, Clostridium and Aeribacillus }\end{array}$ & $\mathrm{AFB}_{1}, \mathrm{ZEN}$, & NA & [88] \\
\hline $\begin{array}{c}\text { Bacterial consortium isolated from spent mushroom } \\
\text { compost: Pseudomonas, Comamonas, Delftia, } \\
\text { Sphingobacterium, Achromobacter }\end{array}$ & $\mathrm{FB}_{1}$ & $\begin{array}{l}\text { Enzymatic transformation into low-toxicity } \\
\text { metabolites }\end{array}$ & [89] \\
\hline
\end{tabular}


Table 1. Cont.

\begin{tabular}{|c|c|c|c|}
\hline Microorganisms & Targeted Mycotoxins & Mechanism & References \\
\hline \multicolumn{4}{|c|}{ Yeasts } \\
\hline Candida guilliermondii & PAT & $\begin{array}{l}\text { Biotransformation into E-ascladiol with short-chain } \\
\text { dehydrogenase/reductase }\end{array}$ & {$[90,91]$} \\
\hline Candida parapsilosis & ZEN & $\begin{array}{l}\text { Biotransformation into less toxic } \beta \text {-zearalenol } \\
(\beta-Z \mathrm{O}) \text { and zearalenone-14,16-diglucosid }\end{array}$ & [92] \\
\hline Candida utilis & ZEN, OTA, AFB 1 & Adsorption into cell wall preparation & [93] \\
\hline Kodameae ohmeri & PAT & Biotransformation into E- and Z-ascladiol & [94] \\
\hline Komagataella phaffi & $\mathrm{FB}_{1}$ & Biotransformation due to fumonisin esterase & [95] \\
\hline Meyerozyma guilliermondii & PAT & Biotransformation into undefined products & [96] \\
\hline Metschnikowia pulcherrima & PAT & Biodegradation & [97] \\
\hline Metschnikowia pulcherrima & OTA & $\begin{array}{c}\text { Biotransformation into undefined productsOT } \alpha \text { and } \\
\text { sodium adduct of OT } \alpha \text { with loss of the } \\
\text { coumarin group }\end{array}$ & {$[98,99]$} \\
\hline Pichia caribbica & PAT & Enzymatic biodegradation & [100] \\
\hline Rhodosporidium kratochvilovae & PAT & Biotransformation into desoxypatulinic acid & {$[101,102]$} \\
\hline Rhodotorula mucilaginosa & PAT & $\begin{array}{l}\text { Enzymatic biotransformation by orotate } \\
\text { phosphoribosyltransferase }\end{array}$ & {$[103,104]$} \\
\hline Saccharomyces cerevisiae & PAT & $\begin{array}{l}\text { Adsorption to proteins and polysaccharides in the } \\
\text { cell walls }\end{array}$ & [105] \\
\hline Saccharomyces cerevisiae & OTA & Adsorption by cell wall polysaccharides & {$[106,107]$} \\
\hline Saccharomyces cerevisiae & OTA & Adsorption & [108] \\
\hline Saccharomyces pastorianus & DON, HT-2, T-2 & Biodegradation and/or adsorption & [109] \\
\hline Saccharomyces cerevisiae, S. pastorianus & DON, ZEN & Adsorption by yeast cells & [110] \\
\hline $\begin{array}{c}\text { Saccharomyces cerevisiae thermal inactivated } \\
\text { cells powder }\end{array}$ & $\mathrm{AOH}, \mathrm{AME}$ & Adsorption & [111] \\
\hline Yarrowia lipolytica & OTA & Biodegradation into less toxic products & [112] \\
\hline $\begin{array}{l}\text { Microorganisms isolated from Kombucha } \\
\text { culture: Pichia occidentalis, Candida sorboxylosa } \\
\text { and Hanseniaspora opuntiae }\end{array}$ & $\mathrm{AFB}_{1}$ & Biodegradation into less toxic products & [113] \\
\hline \multicolumn{4}{|c|}{ Molds } \\
\hline Aspergillus niger & OTA & $\begin{array}{c}\text { Biodegradation into ochratoxin } \alpha \text { by extracellular } \\
\text { ochratoxinase }\end{array}$ & [114] \\
\hline Aspergillus niger & AFB1 & Biodegradation into $\mathrm{AFB}_{2}-\mathrm{GOH}$ & [115] \\
\hline Byssochlamys nivea & PAT & Biodegradation & {$[116,117]$} \\
\hline Clonostachys rosea & ZEA & $\begin{array}{l}\text { Biotransformation into a less toxic product due to } \\
\text { lactonase activity followed by decarboxylation }\end{array}$ & [118] \\
\hline Rhizopus oryzae, Trichoderma reesei & AFs & Biodegradation & [119] \\
\hline Cladosporium uredinicola & AFB1 & Biotransformation into less cytotoxic products & [120] \\
\hline
\end{tabular}

The studies of microbial activity aimed at the removal of mycotoxins discussed so far have been mainly of a scientific nature, allowing for a better understanding of the strains, their properties, and their mechanisms of action, rather than leading to practical applications. Two main methods of microbial decontamination are identified in the literature: adsorption to the cell wall compounds (peptidoglycan, glucomannan, $\beta$-D-glucan) and biotransformation to less toxic or non-toxic compounds, thanks to the expression of appropriate enzymes. Biotransformation takes place along different pathways, by the reduction of ketone carbonyl groups, modification of phenolic hydroxyl groups, the hydrolysis of lactone rings, or the creation of connections with glutathione, deamination, or decarboxylation.

The use of microorganisms or their cell components for the decontamination of foods and feeds could have great potential. However, there are still no legal regulations concerning the decontamination of food detoxification processes that can be applied to products destined for use as animal feed. According to Commission Regulation (EC) 386/2009 in the feed technological additives category, a new functional group was created, composed of "substances for reduction of the contamination of feed by mycotoxins". These are sub- 
stances that can suppress or reduce the absorption of mycotoxins, promote the excretion of mycotoxins, or modify their mode of action, and thereby mitigate possible adverse effects of mycotoxins on animal health [121].

The rules on the detoxification of feed are contained in Commission Regulation (EU) 2015/786. Acceptable detoxification processes should ensure that feed subjected to detoxification processes does not adversely affect the health of either the farm animals or the consumers of food of animal origin (Figure 4). It should also be effective and irreversible, without changing the properties (e.g., nutritional properties) of the feed. The detoxification process should be performed in a facility approved for the purpose by a competent authority. Only detoxification methods that have obtained a positive EFSA scientific opinion and have been approved by competent institutions may be used [122].

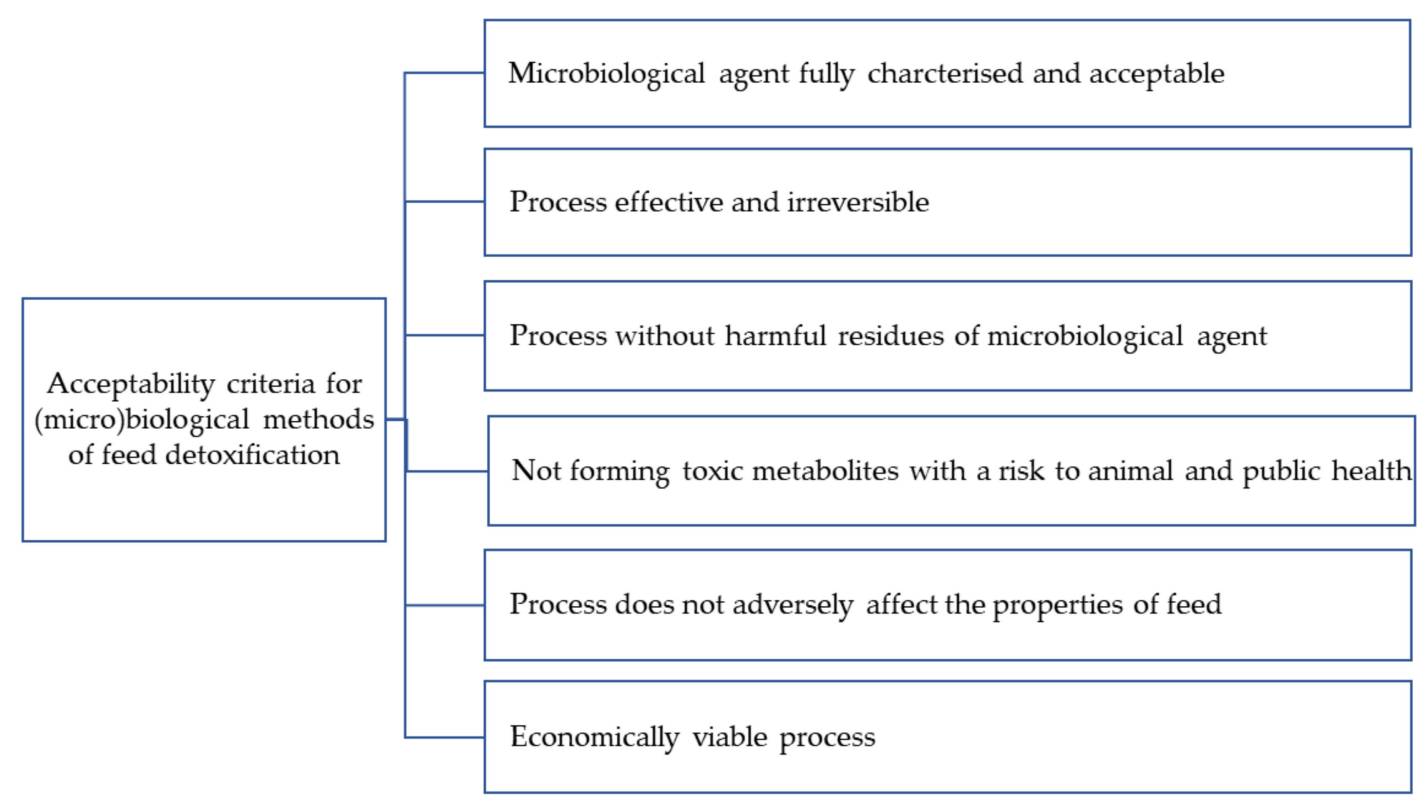

Figure 4. Criteria for acceptability of microbiological decontamination methods.

One of the methods of feed detoxification approved by the relevant institutions is the commercial enzyme-based additive FUMzyme ${ }^{\circledR}$, produced by Biomin $\mathrm{GmbH}$, Austria. This product contains fumonisin esterase, produced by a genetically modified Komagataella pastoris yeasts strain. The additive is already authorized for use with all pigs, all poultry, and all avian species [123]. According to Rychen et al. [95], when added to feed contamination by FB1, fumonisin esterase is able to significantly reduce the concentration of fumonisin B1 in animal feces and at various points in the digestive tract. This is the result of complete or partial fumonisin de-esterification to less toxic products. FUMzyme ${ }^{\circledR}$ does not have any adverse effect on animal health at the recommended maximum dose $300 \mathrm{U} / \mathrm{kg}$ of complete feedstuff. Moreover, it is safe for consumers of animal products [123].

As shown in Figure 4, the first criterion of acceptability for a microbiological decontamination method is a well-characterized and accepted microorganism. Microorganisms that can effectively remove mycotoxins (Table 1) include newly isolated species that have so far been poorly characterized. Cupriavidus spp. belonging to the Burkholderiacea family are relatively poorly understood bacteria, which can be isolated from soil, root nodules, sewage, and aquatic environments [124]. Other examples of newly isolated microorganisms are Pelagibacterium halotolerans, a novel marine halotolerant species of bacteria [125], and Devosia insulae [126]. Only microorganisms that are well known, safe, and characterized in terms of pathogenicity can be used for decontamination. Some of the bacteria and yeasts listed in Table 1 can cause infections in humans. These include Alcaligenes faecalis, which is often associated with local and systemic infections in humans (endocarditis, bacteremia, meningitis, endophthalmitis, skin and soft tissue infections, urinary tract infections, otitis 
media, peritonitis, and pneumonia) [127] and Enterobacter cloceae complex strains [128,129], as well as Candida quilliermondii and C. parapsilosis, which are in the group of six pathogenic species of yeast responsible for invasive candidiasis [130]. Most infections caused by the bacteria and yeasts listed in Table 1 are opportunistic infections.

Safe and practical methods that could potentially be acceptable to consumers include the use of lactic acid bacteria and selected species of yeasts or microorganism enzymes. These methods can be used during biotechnological processes for the production of fermented food, such as dairy products, vegetable silages, wine, beer, or sourdough. However, the levels of mycotoxin contamination in the raw materials should still not exceed the accepted levels established in EU Regulation 1881/2006 [11].

\subsection{Lactic Acid Bacteria}

Lactic acid bacteria, including probiotic strains, are of particular interest due to their beneficial physiological effects on human and animal health and their ability bind mutagens from food and the environment [131]. LAB have traditionally been used as natural food and feed preservatives.

Aflatoxin B1, zearalenone, and ochratoxin A have been found to be effectively bound by Lacticaseibacillus rhamnosus probiotic strains [31,38,132]. El-Nezami et al. [34,133] showed that this process can be very fast. After only $4 \mathrm{~h}$ of contact between the bacteria and AFB1, the initial amount of AFB1 $(5 \mu \mathrm{g} / \mathrm{mL})$ decreased by between $50 \%$ and $77 \%$, depending on the strain, $\mathrm{pH}$, temperature, and biomass density. According to these authors, AFB1 was predominantly bound to the carbohydrate components of cells. Hydrophobic and electrostatic interactions played a major role in this process. Lactobacillus acidophilus and L. rhamnosus strains are also characterized by the ability to remove AFM1 from milk, with effectiveness ranging from $18 \%$ to $57 \%$, depending on the strain [33].

The adsorption of ochratoxin A to the cell wall of Lactiplantibacillus plantarum, Levilactobacillus brevis, and Fructilactobacillus sanfranciscensis has been demonstrated in [70]. Using heat-inactivated lactic acid bacteria biomass, the reduction in the amount of the toxin was several times more efficient than using the same density of viable cell biomass. These findings confirm that toxins are adsorbed into the bacterial cells, especially into the peptidoglycan, as in [34]. The better adsorption of mycotoxins by dead cells compared with live cells may be due to changes in the structures of the bacterial cell walls under the influence of high temperature-i.e., denaturation of proteins, generation of pores in the cell wall structure (which increases the permeability of the outer layers of the cell wall), and increased numbers of active areas responsible for the adsorption of various compounds $[33,70]$.

Niderkorn et al. [134] selected lactic and propionic fermentation bacteria for the removal of Fusarium toxins from solutions. Lacticaseibacillus rhamnosus removed 55\% of deoxynivalenol. Leuconostoc mesenteroides removed $82 \%$ of fumonisin B1, whereas Lactococcus lactis removed $100 \%$ of fumonisin B1. In vivo experiments showed that the use of a synbiotic preparation with selected probiotic strains of the Lactobacillaceae family as feed additives reduced the effects of ochratoxicosis in chickens, as well as having a beneficial influence on the gastrointestinal tract of chickens [135].

Most reports on decontamination by lactic acid bacteria concern aflatoxin B1 and ochratoxin A. The main mechanism responsible for the detoxification of these bacteria is adsorption to the bacterial cell wall. Biotransformations into other products have been reported for patulin and zearalenone (Table 1). Wei et al. [71] tested Lactiplantibacillus plantarum strains isolated from traditional Chinese fermented food for their ability to detoxify patulin. One strain, 13M5, showed the ability to transform patulin into less toxic Eascaladiol. A similar result was obtained by Zheng et al. [72], who used the Lacticaseibacillus casei YZU01 strain to remove patulin from apple and pear juice. However, in this case, as well as the main mechanism of biotransformation into E-ascaladiol, adsorption of the toxin into the bacterial cells was observed. In a study by Chen et al. [74], Lactiplantibacillus 
plantarum strains isolated from faeces and the digestive tracts of leaf-nosed bats and ducks were able to degrade ZEA, due to bacterial esterase activity.

The second condition that a microbiological method must meet is the irreversibility of the process (Figure 4). To avoid desorption and re-exposure to toxins, the mycotoxinadsorbent complex should be stable, especially under gastrointestinal conditions. However, in some cases the adsorbed mycotoxins are released [40,70]. It has been shown in model studies that toxins bound using thermally inactivated LAB cells are more stable than toxins bound using live bacteria [136].

\subsection{Yeasts}

Yeasts are the second group of organisms with important potential applications, especially Saccharomyces cerevisiae strains. These organisms are widely used in many biotechnological processes, such as baking, brewing, winemaking, and distilling. Several studies have shown that yeasts can effectively remove different mycotoxins from plantderived raw materials during fermentation, and in model conditions from microbiological media [41-46,106,108-110].

Patulin in apple and fruit-based food and drink poses a risk to consumer health. Therefore, methods are sought to minimize patulin contamination. Zhang et al. [105] studied patulin adsorption by Saccharomyces cerevisiae during fermentation in a model medium spiked with PAT. After $48 \mathrm{~h}$ of fermentation, almost $90 \%$ of the initial content of PAT was removed. The efficiency of adsorption was found to depend on the duration and temperature of fermentation, as well as the initial PAT concentration. The authors concluded that the toxin was absorbed into the cell wall proteins and polysaccharides. In several studies on patulin removal, a different mechanism was demonstrated. Marine yeast identified as Kodameae ohmeri was able to transform PAT to E- and Z-ascladiol. The efficiency of the process was highest at $\mathrm{pH} 3-6$, temperature $35^{\circ} \mathrm{C}$, and an inoculum density of around $5 \times 10^{8}$ cells $/ \mathrm{mL}$ [94]. After incubation of PAT with Rhodotorula kratochvilovae, which is less toxic than PAT, desoxypatulinic acid was formed. The authors suggest that the lower toxicity of desoxypatulinic acid is a consequence of the hydrolysis of the lactone ring and the loss of functional groups that react with thiol groups [101]. In a study by Reddy et al. [97], patulin was effectively degraded by $87.4 \%$ after $48 \mathrm{~h}$ of fermentation by Metschnikowia pulcherrima. Patulin was not detected in the yeast cell walls, which indicates that the yeast did not adsorb PAT but degraded it to an unidentified product of unknown toxicity.

Mycotoxins, especially those produced by Fusarium pathogens, pose a problem in breweries. Barley malt can be contaminated with ZEN, DON, and their derivatives FUM and OTA, which can be transferred to malting and brewing by-products [137]. The use of appropriate strains of decontaminable yeast in the production process can improve the quality of the finished products. Nathanail et al. [109] demonstrated that Saccharomyces pastorianus lager yeast was able to reduce mycotoxin levels during fermentation of wort naturally contaminated by Fusarium trichothecenes. After the $96 \mathrm{~h}$ of fermentation, reductions in the numbers of mycotoxins were observed of up to $15 \%$ for DON, $17 \%$ for DON-3 glucoside, 34\% for HT2, and 31\% for T2. Since trichothecene metabolites were detected in the beer, the authors suggest that the reactions behind the reduction in mycotoxins may be glucose-sulfate conjugation and deacetylation. Another proposed mechanism was physical binding of the mycotoxins to the yeast cell. Since spent yeast is often used as animal feed, it is important to investigate the stability of the mycotoxin-cell wall complex under gastrointestinal conditions. According to Wall-Martínez et al. [110], the main mechanism of mycotoxin removal during fermentation of contaminated wort is adsorption to the yeast cell wall. After fermentation by the brewer's yeasts S. cerevisiae and S. pastorianus, $10-17 \%$ of DON and $30-70 \%$ of ZEN was removed. The initial concentrations of DON and ZEN in the yeast biomass were $6.4 \%$ and $31.3 \%$, respectively. In unfiltered beers, this can be a problem due to the secondary exposure of consumers to mycotoxins, especially as adsorption is reversible at the low $\mathrm{pH}$ conditions in the gastrointestinal tract. 
Cereals and their derivatives, such as flour and bread, are often contaminated by mycotoxins, mainly OTA and Fusarium toxins. The production of sourdough using Saccharomyces cerevisiae yeast and lactic acid bacteria reduces the mycotoxin content [38] Mozaffary et al. [108] found that during dough fermentation S. cerevisiae baker's yeast was able to reduce the amount of OTA in wheat flour by about $60 \%$.

After cereals, the second major source of exposure to OTA is wine. Ochratoxin A contamination is caused by toxigenic fungi such as Aspergillus carbonarius, A. niger, and A. awamorii, which grow on grapes [138]. Certain oenological strains of Saccharomyces sp. yeasts are able to remove OTA from grape musts during winemaking $[41,106,139,140]$. Cecchini et al. [140] demonstrated that, dependending on the yeast strain, wine yeasts are able to remove $46.8-52.2 \%$ of the OTA in white wine and $53.2-70.1 \%$ of the OTA in red wine during the fermentation process. The absence of degradation products suggested an adsorption mechanism.

The process of removing OTA from grape juice is very fast. In one study, after just $5 \mathrm{~min}$ of contact with yeast cells, $90 \%$ of the initial toxin content $(10 \mu \mathrm{g} / \mathrm{mL})$ was adsorbed [41]. Similar results were obtained during fermentation of white grape and blackcurrant musts. Fermentation with Saccharomyces bayanus resuted in the removal of more than $80 \%$ of the initial content of OTA. Heat-inactivated yeast biomass ( $5 \mathrm{~g}$ dry weight/L) adsorbed more than $60 \%$ of OTA from wine [106]. Different results, indicating biotransformation, were obtained by Freire et al. [141] during fermentation of grape must artificially contaminated with toxigenic strains of $A$. carbonarius and A. niger. The reductions in OTA concentrations ranged from $88.2 \%$ to $92.4 \%$, depending on the type of wine. Metabolites such as ochratoxin B, ochratoxin $\alpha$ methyl ester, ochratoxin B methyl ester, ochratoxin A methyl ester, ethylamide ochratoxin A, ochratoxin C, and ochratoxin A glucose ester were also detected. When red grape must contaminated with OTA was fermented by Metschnikowia pulcherrima, products of OTA biodegradation ( $\alpha$-OTA and the sodium adduct of $\alpha$-OTA without the coumarin group) were identified [99].

Some studies have investigated the possibility of using dead yeast cells from appropriate strains as adsorbents in oenological practice $[41,106]$. Such adsorbents are inexpensive, safe, and do not affect the organoleptic properties of the wine. However, the disposal of the residue is controversial since the toxin can desorb from the yeast cell-OTA complex. Another disadvantage of this method of decontamination is that it binds other ingredients that contribute to wine quality, such as polyphenols and anthocyanins [142]. Petruzzi et al. [143] demonstrated that the process of OTA binding by Saccharomyces cerevisiae is reversible and that the stability of the OTA-yeast cell complex depends on the kind of strain, the $\mathrm{pH}$, and the sugar concentration.

\section{Mycotoxin Adsorbents of Microbial Origin}

Another approach to mycotoxin decontamination is the addition of inert dietary supplements to feed, such as clays, kaolin, zeolites, activated carbon, sodium, and magnesium aluminum silicates, as well as hydrated sodium calcium aluminum silicate (HSCAS) or bentonite [144]. These supplements effectively adsorb toxins in the feed or in the digestive tract of animals. As a result, the toxins are not absorbed into the bloodstream and their resorption is prevented. Various inorganic adsorbents are commercially available and some of them are enriched with enzymes. However, the major disadvantage of adsorbents is that they can also bind vitamins, micro- and macro-elements, as well as other essential compounds, thereby reducing the nutritional value of the feed.

The dominant mechanism responsible for the removal of mycotoxins using microorganisms is adsorption to bacterial and yeast cells. Given the many limitations regarding the use of live microorganisms to remove mycotoxins, the use of microbial adsorbents for this purpose offers a promising solution. Most research has focused on preparations containing $\beta$-D-glucans extracted from S. cerevisiae yeast cell walls. Yeasts cell wall components have been used to adsorb a variety of toxins, including Fusarium and Alternaria toxins, as well as OTA and AFB1 [42,93,107,111,145,146]. In a study by Bzducha et al. [93], the cell walls and 
$\beta$-glucans isolated from Candida utilis were characterized by the greatest ability to bind non-polar mycotoxins, such as ZEN, OTA, and AFB1, especially under acidic conditions. Freimund et al. [42] showed that crosslinked 1,3- $\beta$-D-glucan modified by carboxymethyl ether and hexadecyltrimethylammonium salt was able to efficiently adsorb zearalenone and T-2 toxin.

Research on OTA adsorption under model conditions has shown that the polysaccharide fraction of the brewery yeast cell, water-extracted glucan, and commercial glucan adsorbed the highest amounts of OTA, at more than $55 \%$ of the initial concentration. Adsorption is most effective at a close-to-neutral $\mathrm{pH}$ and is considerably less effective under alkaline conditions. The polysaccharide fraction of the yeast cell wall, namely $\beta$-glucans, is responsible for the adsorption of ochratoxin A [107]. Yiannikouris et al. [147] found that zearalenone adsorption provided by $\beta-(1,3)$-D-glucans is most effective under acidic and neutral conditions. These conditions are present in some parts of the digestive tract of animals, which suggests that $\beta$-(1,3)-D-glucans may be effective as feed additives. Different results were obtained in a study on the adsorption of Alternaria toxins (AOH and AME) by thermally deactivated yeasts. In an alkaline environment at $\mathrm{pH} 9$, the toxins were almost completely removed by the yeast powder at a concentration of $40 \mathrm{~g} / \mathrm{L}$ [111].

Yeasts and their cell wall components are used both as feed additives for animals and as adsorbents that effectively limit mycotoxicosis in farm animals. Raju and Devegowda [148] suggest that the esterified form of $\beta$-D-glucan from yeast cell walls can help to protect broiler chickens exposed to aflatoxin B1, ochratoxin A, and T-2 toxin, individually and in combination. The potential application of glucans and yeast cell wall derivatives as mycotoxin adsorbents in feed depends on the stability of the toxin-cell wall complex under the conditions of the gastrointestinal tract. Analysis of the adsorption of OTA by yeast cell wall extract during simulated consecutive digestion steps revealed that more than $80 \%$ of the OTA was bound at $\mathrm{pH} 2.5$. The resulting complex was stable after the action of digestive enzymes (pepsin, pancreatin). However, some of the OTA was released when the $\mathrm{pH}$ was raised to 6.5 .

An in vivo study on broiler chickens showed that OTA deposits in the livers of chickens given contaminated feed containing cell wall extract were $30 \%$ lower after 14 days than the levels of OTA in the control group given contaminated feed without the extract [149]. This result was supported by Ejiofor et al. [150], who found that the addition of $2 \mathrm{~g}$ of S. cerevisiae yeast to $1 \mathrm{~kg}$ of feed neutralized the negative impact of feed naturally contaminated with AFs and DON on the histopathological, hematological, and serum biochemical parameters of chickens, although to a lesser extent than kaolin adsorbent.

Overall, the research literature suggests that adsorbents can be used as functional feed additives, increasing the efficiency and health of poultry exposed to mycotoxins in feed. These findings may be of interest and use to feed producers and livestock breeders.

\section{Conclusions}

This review has surveyed the literature regarding the removal of mycotoxins from food and feed, with a special focus on microbiological methods. Although the decontamination of food using microorganisms has many advantages, there are still no legal regulations concerning the decontamination of food (Figure 5). Biological detoxification processes can, however, be applied to products used as animal feed.

Methods that could be used safely and be acceptable to consumers include the use of lactic acid bacteria and selected yeast species, which can be used in the production of fermented foods such as dairy products, vegetable silages, wine, beer, and sourdough Selected strains with appropriate technological features could also reduce the content of toxins, increasing the safety of the final product. Another possibility is the addition of dietary supplements to feed, which can effectively adsorb toxins directly in the feed or in the digestive tract of animals. As a result, the toxins are not absorbed into the bloodstream. Yeasts and their cell wall derivatives can be used to adsorb a variety of toxins, including Fusarium and Alternaria toxins, as well as OTA and AFB1. More research is needed to 
ensure that these methods meet the many standards required for practical usage. The environmental risk of residues containing toxins, as well as economic aspects, should also be considered.

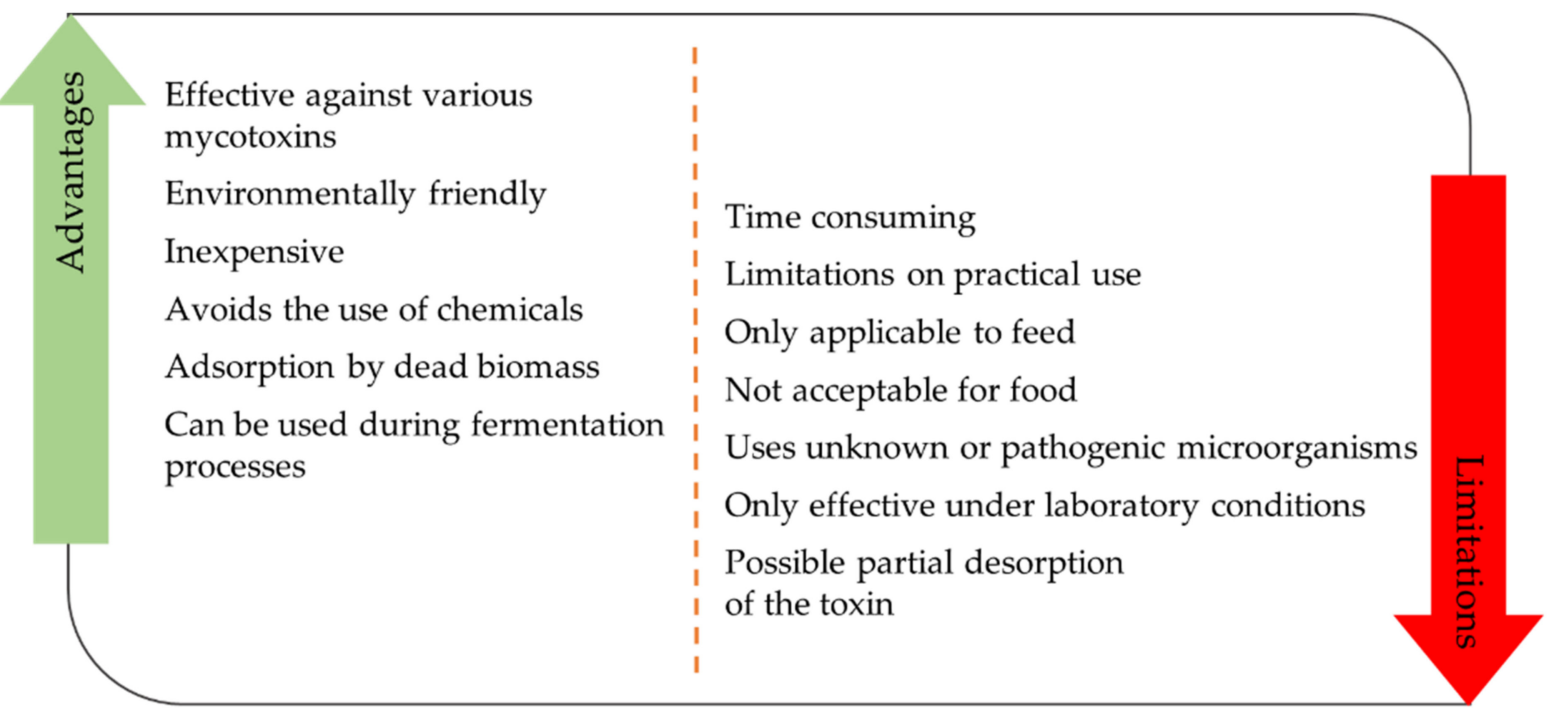

Figure 5. Advantages and limitations of biological methods of decontamination.

Funding: This research received no external funding.

Institutional Review Board Statement: Not applicable.

Informed Consent Statement: Not applicable.

Data Availability Statement: Not applicable.

Conflicts of Interest: The author declares no conflict of interest.

\section{References}

1. Murphy, P.A.; Hendrich, S.; Landgren, C.; Bryant, C.M. Food mycotoxins: An update. J. Food Sci. 2006, 71, R51-R65. [CrossRef]

2. Richard, J.L. Some major mycotoxins and their mycotoxicoses-An overview. Int. J. Food Microbiol. 2007, 119, 3-10. [CrossRef] [PubMed]

3. Alassane-Kpembi, I.; Schatzmayr, G.; Taranu, I.; Marin, D.; Puel, O.; Oswald, I.P. Mycotoxins co-contamination: Methodological aspects and biological relevance of combined toxicity studies. Crit. Rev. Food Sci. Nutr. 2017, 57, 3489-3507. [CrossRef]

4. European Commission. Commission Regulation (EU) 2019/1901 of 7 November 2019 amending Regulation (EC) No 1881/2006 as regards maximum levels of citrinin in food supplements based on rice fermented with red yeast Monascus purpureus. Off. $J$. Eur. Union 2019, 62, 2-4.

5. European Commission. Commission Regulation (EU) 2015/1137 of 13 July 2015 amending Regulation (EC) No $1881 / 2006$ as regards the maximum level of Ochratoxin A in Capsicum spp. spices. Off. J. Eur. Union 2015, 58, 11-12.

6. European Commission. Commission Regulation (EU) No 1058/2012 of 12 November 2012 amending Regulation (EC) No 1881/2006 as regards maximum levels for aflatoxins in dried figs. Off. J. Eur. Union 2012, 55, 14-15.

7. European Commission. Commission Regulation (EU) No 594/2012 of 5 July 2012 amending Regulation (EC) $1881 / 2006$ as regards the maximum levels of the contaminants ochratoxin A, non dioxin-like PCBs and melamine in foodstuffs. Off. J. Eur. Union 2012, 55, 43-45.

8. European Commission. Commission Regulation (EU) No 165/2010 of 26 February 2010 amending Regulation (EC) No 1881/2006 setting maximum levels for certain contaminants in foodstuffs as regards aflatoxins. Off. J. Eur. Union 2010, 50, 8-12.

9. European Commission. Commission Regulation (EU) No 105/2010 of 5 February 2010 amending Regulation (EC) No 1881/2006 setting maximum levels for certain contaminants in foodstuffs as regards ochratoxin A. Off. J. Eur. Union 2010, 53, 7-8.

10. European Commission. Commission Regulation (EC) No 1126/2007 of 28 September 2007 amending Regulation (EC) No $1881 / 2006$ setting maximum levels for certain contaminants in foodstuffs as regards Fusarium toxins in maize and maize products. Off. J. Eur. Union 2007, 50, 14-18.

11. European Commission. Commission Regulation (EC) No 1881/2006 of 19 December 2006. Setting maximum levels for certain contaminants in foodstuffs. Off. J. Eur. Union 2006, 364, 324-365. 
12. European Commission. Commission Recommendation of 17 August 2006 on the presence of deoxynivalenol, zearalenone, ochratoxin A, T-2 and HT-2 and fumonisins in products intended for animal feeding. Off. J. Eur. Union 2006, 49, 7-9.

13. Boutrif, E.; Canet, C. Mycotoxin prevention and control: FAO programmes. Rev. Med. Vet. 1998, 149, 681-694.

14. Eskola, M.; Kos, G.; Elliott, C.T.; Hajslova, J.; Mayar, S.; Krska, R. Worldwide contamination of food-crops with mycotoxins: Validity of the widely cited 'FAO estimate' of 25\%. Crit. Rev. Food Sci. Nutr. 2020, 60, 2773-2789. [CrossRef]

15. Lee, H.J.; Ryu, D. Worldwide occurrence of mycotoxins in cereals and cereal-derived food products: Public Health Perspectives of Their Co-occurrence. J. Agric. Food Chem. 2017, 65, 7034-7051. [CrossRef] [PubMed]

16. Biomin. Mycotoxin Survey. Occurrence and Risk Level Indicator. Available online: https://www.biomin.net/solutions/mycotoxinsurvey (accessed on 12 October 2021).

17. Zhang, Z.; Nie, D.; Fan, K.; Yang, J.; Guo, W.; Meng, J.; Zhao, Z.; Han, Z. A systematic review of plant-conjugated masked mycotoxins: Occurrence, toxicology, and metabolism. Crit. Rev. Food Sci. Nutr. 2019, 60, 1523-1537. [CrossRef] [PubMed]

18. European Commission. Commission Recommendation of 17 August 2006 on the prevention and reduction of Fusarium toxins in cereals and cereal products. Off. J. Eur. Union 2006, 49, 35-40.

19. Nunes, V.M.; Moosavi, M.; Khaneghah, A.M.; Oliveira, C.A. Innovative modifications in food processing to reduce the levels of mycotoxins. Curr. Opin. Food Sci. 2021, 38, 155-161. [CrossRef]

20. Marshall, H.; Meneely, J.P.; Quinn, B.; Zhao, Y.; Bourke, P.; Gilmore, B.F.; Zhang, G.; Elliott, C.T. Novel decontamination approaches and their potential application for post-harvest aflatoxin control. Trends Food Sci. Technol. 2020, 106, 489-496. [CrossRef]

21. Conte, G.; Fontanelli, M.; Galli, F.; Cotrozzi, L.; Pagni, L.; Pellegrini, E. Mycotoxins in feed and food and the role of ozone in their detoxification and degradation: An Update. Toxins 2020, 12, 486. [CrossRef] [PubMed]

22. Ciegler, A.; Lillehoj, E.B.; Peterson, R.E.; Hall, H.H. Microbial detoxification of aflatoxin. Appl. Microbiol. 1966, 14, 934-939. [CrossRef]

23. Dsouza, D.; Brackett, R.E. Aflatoxin B1 degradation by Flavobacterium aurantiacum in the presence of reducing conditions and seryl and sulfhydryl group inhibitors. J. Food Prot. 2001, 64, 268-271. [CrossRef] [PubMed]

24. Hao, Y.-Y.; Brackett, R.E. Removal of aflatoxin B1 from peanut milk inoculated with Flavobacterium aurantiacum. J. Food Sci. 1988 53, 1384-1386. [CrossRef]

25. Line, J.E.; Brackett, R.E. Factors aAffecting aflatoxin B1 removal by Flavobacterium aurantiacum. J. Food Prot. 1995, 58, 91-94. [CrossRef] [PubMed]

26. Smiley, R.D.; Draughon, F.A. Preliminary evidence that degradation of aflatoxin B1 by Flavobacterium aurantiacum is enzymatic. J. Food Prot. 2000, 63, 415-418. [CrossRef]

27. Teniola, O.; Addo, P.; Brost, I.; Farber, P.; Jany, K.; Alberts, J.; Vanzyl, W.; Steyn, P.; Holzapfel, W. Degradation of aflatoxin B1 by cell-free extracts of Rhodococcus erythropolis and Mycobacterium fluoranthenivorans sp. nov. DSM44556T. Int. J. Food Microbiol. 2005, 105, 111-117. [CrossRef]

28. Hwang, C.-A.; DraughonN, F.A. Degradation of ochratoxin A by Acinetobacter calcoaceticus. J. Food Prot. 1994, 57, 410-414. [CrossRef]

29. Engler, K.H.; Coker, R.D.; Evans, I.H. Uptake of aflatoxin B 1 and T-2 toxin by two mycotoxin bioassay microorganisms: Kluyveromyces marxianus and Bacillus megaterium. Arch. Microbiol. 2000, 174, 381-385. [CrossRef]

30. Mateo, E.M.; Medina, Á.; Mateo, F.; Valle-Algarra, F.M.; Pardo, I.; Jiménez, M. Ochratoxin A removal in synthetic media by living and heat-inactivated cells of Oenococcus oeni isolated from wines. Food Control. 2010, 21, 23-28. [CrossRef]

31. Peltonen, K.D.; El-Nezami, H.S.; Salminen, S.J.; Ahokas, J.T. Binding of aflatoxin B1 by probiotic bacteria. J. Sci. Food Agric. 2000, 80, 1942-1945. [CrossRef]

32. Fuchs, S.; Sontag, G.; Stidl, R.; Ehrlich, V.; Kundi, M.; Knasmüller, S. Detoxification of patulin and ochratoxin A, two abundant mycotoxins, by lactic acid bacteria. Food Chem. Toxicol. 2008, 46, 1398-1407. [CrossRef] [PubMed]

33. Pierides, M.; El-Nezami, H.; Peltonen, K.; Salminen, S.; Ahokas, J. Ability of dairy strains of lactic acid bacteria to bind aflatoxin M1 in a food model. J. Food Prot. 2000, 63, 645-650. [CrossRef]

34. El-Nezami, H.; Kankaanpaa, P.; Salminen, P.; Ahokas, J. Ability of dairy strains of lactic acid bacteria to bind a common food carcinogen, aflatoxin B1. Food Chem. Toxicol. 1998, 36, 321-326. [CrossRef]

35. El-Nezami, H.; Mykkänen, H.; Kankaanpää, P.; Salminen, S.; Ahokas, J. Ability of Lactobacillus and Propionibacterium strains to remove aflatoxin B1 from the chicken duodenum. J. Food Prot. 2000, 63, 549-552. [CrossRef]

36. Turbic, A.; Ahokas, J.T.; Haskard, C.A. Selective in vitro binding of dietary mutagens, individually or in combination, by lactic acid bacteria. Food Addit. Contam. 2002, 19, 144-152. [CrossRef]

37. Škrinjar, M.; Rašić, J.L.; Stojičić, V. Lowering of ochratoxin A level in milk by yoghurt bacteria and bifidobacteria. Folia Microbiol. 1996, 41, 26-28. [CrossRef] [PubMed]

38. Piotrowska, M.; Żakowska, Z. The biodegradation of ochratoxin A in food products by lactic acid bacteria and baker's yeast. Prog. Biotechnol. 2000, 17, 307-310. [CrossRef]

39. Niderkorn, V.; Boudra, H.; Morgavi, D. Binding of Fusarium mycotoxins by fermentative bacteria in vitro. J. Appl. Microbiol. 2006, 101, 849-856. [CrossRef]

40. Haskard, C.A.; El-Nezami, H.S.; Kankaanpaa, P.E.; Salminen, S.; Ahokas, J. Surface binding of aflatoxin B1 by lactic acid bacteria. Appl. Environ. Microbiol. 2001, 67, 3086-3091. [CrossRef] [PubMed] 
41. Bejaoui, H.; Mathieu, F.; Taillandier, P.; Lebrihi, A. Ochratoxin A removal in synthetic and natural grape juices by selected oenological Saccharomyces strains. J. Appl. Microbiol. 2004, 97, 1038-1044. [CrossRef] [PubMed]

42. Freimund, S.; Sauter, M.; Rys, P. Efficient adsorption of the mycotoxins zearalenone and T-2 toxin on a modified yeast glucan. J. Environ. Sci. Heal. Part B 2003, 38, 243-255. [CrossRef] [PubMed]

43. Shetty, P.H.; Hald, B.; Jespersen, L. Surface binding of aflatoxin B1 by Saccharomyces cerevisiae strains with potential decontaminating abilities in indigenous fermented foods. Int. J. Food Microbiol. 2007, 113, 41-46. [CrossRef] [PubMed]

44. Angioni, A.; Caboni, P.; Garau, A.; Farris, A.; Orro, D.; Budroni, M.; Cabras, P. In vitro interaction between ochratoxin A and different strains of Saccharomyces cerevisiae and Kloeckera apiculata. J. Agric. Food Chem. 2007, 55, 2043-2048. [CrossRef] [PubMed]

45. Štyriak, I.; Conková, E.; Kmec, V.; Böhm, J.; Razzazi, E. The use of yeast for microbial degradation of some selected mycotoxins. Mycotoxin Res. 2001, 17, 24-27. [CrossRef] [PubMed]

46. Var, I.; Erginkaya, Z.; Kabak, B. Reduction of ochratoxin A levels in white wine by yeast treatments. J. Inst. Brew. 2009, 115, 30-34. [CrossRef]

47. Abrunhosa, L.; Santos, L.; Venâncio, A. Degradation of ochratoxin A by proteases and by a crude enzyme of Aspergillus niger. Food Biotechnol. 2006, 20, 231-242. [CrossRef]

48. Bejaoui, H.; Mathieu, F.; Taillandier, P.; Lebrihi, A. Conidia of black Aspergilli as new biological adsorbents for ochratoxin A in grape juices and musts. J. Agric. Food Chem. 2005, 53, 8224-8229. [CrossRef]

49. Brown, R.L.; Cotty, P.J.; Cleveland, T.E. Reduction in aflatoxin content of maize by atoxigenic strains of Aspergillus flavus. J. Food Prot. 1991, 54, 623-626. [CrossRef]

50. Varga, J.; Péteri, Z.; Tábori, K.; Téren, J.; Vágvölgyi, C. Degradation of ochratoxin A and other mycotoxins by Rhizopus isolates. Int. J. Food Microbiol. 2005, 99, 321-328. [CrossRef]

51. Varga, J.; Rigó, K.; Téren, J. Degradation of ochratoxin A by Aspergillus species. Int. J. Food Microbiol. 2000, 59, 1-7. [CrossRef]

52. Zhang, H.H.; Wang, Y.; Zhao, C.; Wang, J.; Zhang, X.L. Biodegradation of ochratoxin A by Alcaligenes faecalis isolated from soil. J. Appl. Microbiol. 2017, 123, 661-668. [CrossRef] [PubMed]

53. Chang, X.; Wu, Z.; Wu, S.; Dai, Y.; Sun, C. Degradation of ochratoxin A by Bacillus amyloliquefaciens ASAG1. Food Addit. Contam. Part A 2015, 32, 564-571. [CrossRef] [PubMed]

54. Lee, A.; Cheng, K.-C.; Liu, J.-R. Isolation and characterization of a Bacillus amyloliquefaciens strain with zearalenone removal ability and its probiotic potential. PLoS ONE 2017, 12, e0182220. [CrossRef]

55. Hsu, T.-C.; Yi, P.-J.; Lee, T.-Y.; Liu, J.-R. Probiotic characteristics and zearalenone-removal ability of a Bacillus licheniformis strain. PLoS ONE 2018, 13, e0194866. [CrossRef]

56. Shang, L.; Bai, X.; Chen, C.; Liu, L.; Li, M.; Xia, X.; Wang, Y. Isolation and identification of a Bacillus megaterium strain with ochratoxin A removal ability and antifungal activity. Food Control. 2019, 106, 106743. [CrossRef]

57. Wang, G.; Yu, M.; Dong, F.; Shi, J.; Xu, J. Esterase activity inspired selection and characterization of zearalenone degrading bacteria Bacillus pumilus ES-21. Food Control. 2017, 77, 57-64. [CrossRef]

58. Watanakij, N.; Visessanguan, W.; Petchkongkaew, A. Aflatoxin B1-degrading activity from Bacillus subtilis BCC 42005 isolated from fermented cereal products. Food Addit. Contam. Part A 2020, 37, 1579-1589. [CrossRef] [PubMed]

59. Jia, R.; Cao, L.; Liu, W.; Shen, Z. Detoxification of deoxynivalenol by Bacillus subtilis ASAG 216 and characterization the degradation process. Eur. Food Res. Technol. 2020, 247, 67-76. [CrossRef]

60. Shi, L.; Liang, Z.; Li, J.; Hao, J.; Xu, Y.; Huang, K.; Tian, J.; He, X.; Xu, W. Ochratoxin A biocontrol and biodegradation by Bacillus subtilis CW 14. J. Sci. Food Agric. 2014, 94, 1879-1885. [CrossRef]

61. Bin Yang, S.; Zheng, H.C.; Xu, J.Y.; Zhao, X.Y.; Shu, W.J.; Li, X.M.; Song, H.; Ma, Y.H. New biotransformation mode of zearalenone identified in Bacillus subtilis Y816 revealing a novel ZEN conjugate. J. Agric. Food Chem. 2021, 69, 7409-7419. [CrossRef] [PubMed]

62. Shu, X.; Wang, Y.; Zhou, Q.; Li, M.; Hu, H.; Ma, Y.; Chen, X.; Ni, J.; Zhao, W.; Huang, S.; et al. Biological degradation of aflatoxin B1 by cell-free extracts of Bacillus velezensis DY3108 with broad pH stability and excellent thermostability. Toxins 2018, 10, 330. [CrossRef]

63. Rodriguez, H.; Reveron, I.; Doria, F.; Costantini, A.; Rivas, B.D.L.; Muňoz, R.; Garcia-Moruno, E. Degradation of ochratoxin A by Brevibacterium species. J. Agric. Food Chem. 2011, 59, 10755-10760. [CrossRef]

64. Al-Nussairawi, M.; Risa, A.; Garai, E.; Varga, E.; Szabó, I.; Csenki-Bakos, Z.; Kriszt, B.; Cserháti, M. Mycotoxin biodegradation ability of the Cupriavidus genus. Curr. Microbiol. 2020, 77, 2430-2440. [CrossRef] [PubMed]

65. Ferenczi, S.; Cserháti, M.; Krifaton, C.; Szoboszlay, S.; Kukolya, J.; Szőke, Z.; Kőszegi, B.; Albert, M.; Barna, T.; Mézes, M.; et al. A new ochratoxin A biodegradation strategy using Cupriavidus basilensis Ör16 Strain. PLoS ONE 2014, 9, e109817. [CrossRef]

66. Wang, G.; Wang, Y.; Ji, F.; Xu, L.; Yu, M.; Shi, J.; Xu, J. Biodegradation of deoxynivalenol and its derivatives by Devosia insulae A16. Food Chem. 2019, 276, 436-442. [CrossRef]

67. Wang, L.; Wu, J.; Liu, Z.; Shi, Y.; Liu, J.; Xu, X.; Hao, S.; Mu, P.; Deng, F.; Deng, Y. Aflatoxin B1 Degradation and detoxification by Escherichia coli CG1061 isolated from chicken cecum. Front. Pharmacol. 2019, 9, 9. [CrossRef]

68. Xing, M.; Li, B.; Chen, Y.; Tian, S. Ribonucleoside diphosphate reductase plays an important role in patulin degradation by Enterobacter cloacae subsp. dissolvens. J. Agric. Food Chem. 2020, 68, 5232-5240. [CrossRef] [PubMed]

69. Markov, K.; Frece, J.; Pleadin, J.; Bevardi, M.; Barišić, L.; Kljusurić, J.G.; Vulić, A.; Jakopović, Ž.; Mrvčić, J. Gluconobacter oxydans-Potential biological agent for binding or biotransformation of mycotoxins. World Mycotoxin J. 2019, 12, $153-161$. [CrossRef] 
70. Piotrowska, M. The Adsorption of ochratoxin A by Lactobacillus species. Toxins 2014, 6, 2826-2839. [CrossRef] [PubMed]

71. Wei, C.; Yu, L.; Qiao, N.; Wang, S.; Tian, F.; Zhao, J.; Zhang, H.; Zhai, Q.; Chen, W. The characteristics of patulin detoxification by Lactobacillus plantarum 13M5. Food Chem. Toxicol. 2020, 146, 111787. [CrossRef]

72. Zheng, X.; Wei, W.; Rao, S.; Gao, L.; Li, H.; Yang, Z. Degradation of patulin in fruit juice by a lactic acid bacteria strain Lactobacillus casei YZU01. Food Control. 2020, 112, 107147. [CrossRef]

73. Zhao, L.; Jin, H.; Lan, J.; Zhang, R.; Ren, H.; Zhang, X.; Yu, G. Detoxification of zearalenone by three strains of Lactobacillus plantarum from fermented food in vitro. Food Control. 2015, 54, 158-164. [CrossRef]

74. Chen, S.-W.; Hsu, J.-T.; Chou, Y.-A.; Wang, H.-T. The application of digestive tract lactic acid bacteria with high esterase activity for zearalenone detoxification. J. Sci. Food Agric. 2018, 98, 3870-3879. [CrossRef] [PubMed]

75. Wang, J.; Yang, F.; Yang, P.; Liu, J.; Lv, Z. Microbial reduction of zearalenone by a new isolated Lysinibacillus sp. ZJ-2016-1. World Mycotoxin J. 2018, 11, 571-578. [CrossRef]

76. Wei, W.; Qian, Y.; Wu, Y.; Chen, Y.; Peng, C.; Luo, M.; Xu, J.; Zhou, Y. Detoxification of ochratoxin A by Lysobacter sp. CW239 and characteristics of a novel degrading gene carboxypeptidase cp4. Environ. Pollut. 2020, 258, 113677. [CrossRef]

77. Zhang, H.; Zhang, H.; Qin, X.; Wang, X.; Wang, Y.; Bin, Y.; Xie, X.; Zheng, F.; Luo, H. Biodegradation of deoxynivalenol by Nocardioides sp. ZHH-013: 3-keto-deoxynivalenol and 3-epi-deoxynivalenol as intermediate products. Front. Microbiol. 2021, 12, 12. [CrossRef] [PubMed]

78. Abrunhosa, L.; Inês, A.; Rodrigues, A.; Guimarães, A.; Pereira, V.; Parpot, P.; Mendes-Faia, A.; Venâncio, A. Biodegradation of ochratoxin A by Pediococcus parvulus isolated from Douro wines. Int. J. Food Microbiol. 2014, 188, 45-52. [CrossRef]

79. Zhang, J.; Qin, X.; Guo, Y.; Zhang, Q.; Ma, Q.; Ji, C.; Zhao, L. Enzymatic degradation of deoxynivalenol by a novel bacterium, Pelagibacterium halotolerans ANSP101. Food Chem. Toxicol. 2020, 140, 111276. [CrossRef]

80. Yao, Y.; Shu, X.; Wang, D.; Kan, W.; Su, P.; Hu, H.; Chen, X.; Wang, D.; Huang, S.; Wu, L. Non-enzymatic transformation of aflatoxin B1 by Pseudomonas geniculata m29. Front. Microbiol. 2021, 12, 12. [CrossRef]

81. Prettl, Z.; Dési, E.; Lepossa, A.; Kriszt, B.; Kukolya, J.; Nagy, E. Biological degradation of aflatoxin B 1 by a Rhodococcus pyridinivorans strain in by-product of bioethanol. Anim. Feed. Sci. Technol. 2017, 224, 104-114. [CrossRef]

82. Kriszt, R.; Krifaton, C.; Szoboszlay, S.; Cserháti, M.; Kriszt, B.; Kukolya, J.; Czéh, Á.; Fehér-Tóth, S.; Török, L.; Szőke, Z.; et al. A new zearalenone biodegradation strategy using non-pathogenic Rhodococcus pyridinivorans K408 strain. PLoS ONE 2012, 7, e43608. [CrossRef] [PubMed]

83. Cserháti, M.; Kriszt, B.; Krifaton, C.; Szoboszlay, S.; Háhn, J.; Tóth, S.; Nagy, I.; Kukolya, J. Mycotoxin-degradation profile of Rhodococcus strains. Int. J. Food Microbiol. 2013, 166, 176-185. [CrossRef]

84. Li, Z.; Wang, Y.; Liu, Z.; Jin, S.; Pan, K.; Liu, H.; Liu, T.; Li, X.; Zhang, C.; Luo, X.; et al. Biological detoxification of fumonisin by a novel carboxylesterase from Sphingomonadales bacterium and its biochemical characterization. Int. J. Biol. Macromol. 2021, 169, 18-27. [CrossRef]

85. Campos-Avelar, I.; de la Noue, A.C.; Durand, N.; Cazals, G.; Martinez, V.; Strub, C.; Fontana, A.; Schorr-Galindo, S. Aspergillus flavus growth inhibition and aflatoxin $\mathrm{B}_{1}$ decontamination by Streptomyces isolates and their metabolites. Toxins 2021, 13, 340. [CrossRef]

86. Wang, Y.; Wang, G.; Dai, Y.; Wang, Y.; Lee, Y.-W.; Shi, J.; Xu, J. Biodegradation of deoxynivalenol by a novel microbial consortium. Front. Microbiol. 2020, 10, 2964. [CrossRef]

87. Ben Taheur, F.; Fedhila, K.; Chaieb, K.; Kouidhi, B.; Bakhrouf, A.; Abrunhosa, L. Adsorption of aflatoxin B1, zearalenone and ochratoxin A by microorganisms isolated from Kefir grains. Int. J. Food Microbiol. 2017, 251, 1-7. [CrossRef]

88. Wang, Y.; Zhao, C.; Zhang, D.; Zhao, M.; Zheng, D.; Peng, M.; Cheng, W.; Guo, P.; Cui, Z. Simultaneous degradation of aflatoxin B1 and zearalenone by a microbial consortium. Toxicon 2018, 146, 69-76. [CrossRef] [PubMed]

89. Zhao, Z.; Zhang, Y.; Gong, A.; Liu, N.; Chen, S.; Zhao, X.; Li, X.; Chen, L.; Zhou, C.; Wang, J. Biodegradation of mycotoxin fumonisin B1 by a novel bacterial consortium SAAS79. Appl. Microbiol. Biotechnol. 2019, 103, 7129-7140. [CrossRef]

90. Chen, Y.; Peng, H.-M.; Wang, X.; Li, B.-Q.; Long, M.-Y.; Tian, S.-P. Biodegradation mechanisms of patulin in Candida guilliermondii: An iTRAQ-based proteomic analysis. Toxins 2017, 9, 48. [CrossRef] [PubMed]

91. Xing, M.; Chen, Y.; Li, B.; Tian, S. Characterization of a short-chain dehydrogenase/reductase and its function in patulin biodegradation in apple juice. Food Chem. 2021, 348, 129046. [CrossRef]

92. Pan, Y.; Liu, C.; Yang, J.; Tang, Y. Conversion of zearalenone to $\beta$-zearalenol and zearalenone-14,16-diglucoside by Candida parapsilosis ATCC 7330. Food Control. 2022, 131, 108429. [CrossRef]

93. Bzducha-Wróbel, A.; Bryła, M.; Gientka, I.; Błażejak, S.; Janowicz, M. Candida utilis ATCC 9950 cell walls and $\beta(1,3) /(1,6)$-glucan preparations produced using agro-waste as a mycotoxins Trap. Toxins 2019, 11, 192. [CrossRef]

94. Dong, X.; Jiang, W.; Li, C.; Ma, N.; Xu, Y.; Meng, X. Patulin biodegradation by marine yeast Kodameae ohmeri. Food Addit. Contam. Part A 2015, 32, 1-9. [CrossRef]

95. Rychen, G.; Aquilina, G.; Azimonti, G.; Bampidis, V.; Bastos, M.D.L.; Bories, G.; Chesson, A.; Cocconcelli, P.S.; Flachowsky, G.; Gropp, J.; et al. Safety and efficacy of fumonisin esterase (FUMzyme®) as a technological feed additive for all avian species. EFSA J. 2016, 14, 14. [CrossRef]

96. Fu, Y.; Yang, Q.; Solairaj, D.; Godana, E.A.; Routledge, M.N.; Zhang, H. Biodegradation of mycotoxin patulin by the yeast Meyerozyma guilliermondii. Biol. Control. 2021, 160, 104692. [CrossRef] 
97. Reddy, K.R.N.; Spadaro, D.; Gullino, M.L.; Garibaldi, A. Potential of two Metschnikowia pulcherrima (yeast) strains for in vitro biodegradation of patulin. J. Food Prot. 2011, 74, 154-156. [CrossRef] [PubMed]

98. Patharajan, S.; Reddy, K.; Karthikeyan, V.; Spadaro, D.; Lore, A.; Gullino, M.; Garibaldi, A. Potential of yeast antagonists on invitro biodegradation of ochratoxin A. Food Control. 2011, 22, 290-296. [CrossRef]

99. Mínguez, C.L.; Garrigues, M.A.R.; Ocaña, L.L.; Novella, R.A.; Vinuesa, J.M.; Meca, G. Transformation of ochratoxin A by microorganisms isolated from Tempranillo grapes in wine systems. Am. J. Enol. Vitic. 2020, 71, 167-174. [CrossRef]

100. Zheng, X.; Yang, Q.; Zhang, H.; Cao, J.; Zhang, X.; Apaliya, M.T. The possible mechanisms involved in degradation of patulin by Pichia caribbica. Toxins 2016, 8, 289. [CrossRef]

101. Castoria, R.; Mannina, L.; Durán-Patrón, R.; Maffei, F.; Sobolev, A.P.; De Felice, D.V.; Pinedo-Rivilla, C.; Ritieni, A.; Ferracane, R.; Wright, S.A.I. Conversion of the mycotoxin patulin to the less toxic desoxypatulinic acid by the biocontrol yeast Rhodosporidium kratochvilovae strain LS11. J. Agric. Food Chem. 2011, 59, 11571-11578. [CrossRef]

102. Pinedo, C.; Wright, S.A.I.; Collado, I.G.; Goss, R.J.M.; Castoria, R.; Hrelia, P.; Maffei, F.; Durán-Patrón, R. Isotopic labeling studies reveal the patulin detoxification pathway by the bBiocontrol yeast Rhodotorula kratochvilovae LS11. J. Nat. Prod. 2018, 81, 2692-2699. [CrossRef]

103. Tang, H.; Li, X.; Zhang, F.; Meng, X.; Liu, B. Biodegradation of the mycotoxin patulin in apple juice by orotate phosphoribosyltransferase from Rhodotorula mucilaginosa. Food Control. 2019, 100, 158-164. [CrossRef]

104. Li, X.; Tang, H.; Yang, C.; Meng, X.; Liu, B. Detoxification of mycotoxin patulin by the yeast Rhodotorula mucilaginosa. Food Control. 2019, 96, 47-52. [CrossRef]

105. Zhang, Z.; Li, M.; Wu, C.; Peng, B. Physical adsorption of patulin by Saccharomyces cerevisiae during fermentation. J. Food Sci. Technol. 2019, 56, 2326-2331. [CrossRef]

106. Piotrowska, M.; Nowak, A.; Czyzowska, A. Removal of ochratoxin A by wine Saccharomyces cerevisiae strains. Eur. Food Res. Technol. 2013, 236, 441-447. [CrossRef]

107. Piotrowska, M.; Masek, A. Saccharomyces cerevisiae cell wall components as tools for ochratoxin A decontamination. Toxins 2015, 7, 1151-1162. [CrossRef] [PubMed]

108. Mozaffary, P.; Milani, J.M.; Heshmati, A. The influence of yeast level and fermentation temperature on ochratoxin A decrement during bread making. Food Sci. Nutr. 2019, 7, 2144-2150. [CrossRef] [PubMed]

109. Nathanail, A.V.; Gibson, B.; Han, L.; Peltonen, K.; Ollilainen, V.; Jestoi, M.; Laitila, A. The lager yeast Saccharomyces pastorianus removes and transforms Fusarium trichothecene mycotoxins during fermentation of brewer's wort. Food Chem. 2016, 203, 448-455. [CrossRef]

110. Wall-Martínez, H.A.; Pascari, X.; Bigordà, A.; Ramos, A.J.; Marín, S.; Sanchis, V. The fate of Fusarium mycotoxins (deoxynivalenol and zearalenone) through wort fermenting by Saccharomyces yeasts (S. cerevisiae and S. pastorianus). Food Res. Int. 2019, $126,108587$. [CrossRef] [PubMed]

111. Wang, X.; Han, Y.; Zhang, L.; Ge, Z.; Liu, M.; Zhao, G.; Zong, W. Removal of Alternaria mycotoxins from aqueous solution by inactivated yeast powder. J. Sci. Food Agric. 2020, 100, 5182-5190. [CrossRef]

112. Yang, Q.; Wang, J.; Zhang, H.; Li, C.; Zhang, X. Ochratoxin A is degraded by Yarrowia lipolytica and generates non-toxic degradation products. World Mycotoxin J. 2016, 9, 269-278. [CrossRef]

113. Ben Taheur, F.; Mansour, C.; Ben Jeddou, K.; Machreki, Y.; Kouidhi, B.; Abdulhakim, J.A.; Chaieb, K. Aflatoxin B1 degradation by microorganisms isolated from Kombucha culture. Toxicon 2020, 179, 76-83. [CrossRef] [PubMed]

114. Zhao, M.; Wang, X.; Xu, S.; Yuan, G.; Shi, X.; Liang, Z. Degradation of ochratoxin A by supernatant and ochratoxinase of Aspergillus niger W-35 isolated from cereals. World Mycotoxin J. 2020, 13, 287-298. [CrossRef]

115. Qiu, T.; Wang, H.; Yang, Y.; Yu, J.; Ji, J.; Sun, J.; Zhang, S.; Sun, X. Exploration of biodegradation mechanism by AFB1-degrading strain Aspergillus niger FS10 and its metabolic feedback. Food Control. 2021, 121, 107609. [CrossRef]

116. Zhang, X.; Guo, Y.; Ma, Y.; Chai, Y.; Li, Y. Biodegradation of patulin by a Byssochlamys nivea strain. Food Control. 2016, 64, 142-150. [CrossRef]

117. Zhao, G.; Yang, X.; Nisar, T.; Tian, Y.; Sun, L.; Zhang, X.; Guo, Y. Patulin biodegradation and quality improvement of apple puree fermented with Byssochlamys nivea FF1-2. Food Biosci. 2018, 21, 45-52. [CrossRef]

118. Utermark, J.; Karlovsky, P. Role of zearalenone lactonase in pProtection of Gliocladium roseum from fungitoxic effects of the mycotoxin zearalenone. Appl. Environ. Microbiol. 2007, 73, 637-642. [CrossRef] [PubMed]

119. Hackbart, H.C.S.; Machado, A.R.; Christ-Ribeiro, A.; Prietto, L.; Badiale-Furlong, E. Reduction of aflatoxins by Rhizopus oryzae and Trichoderma reesei. Mycotoxin Res. 2014, 30, 141-149. [CrossRef]

120. Ernuo, T.; Xin, D.; Wenhao, C.; Changgao, W.; Jianguo, L.; Cai, J. Structure and toxicity analysis of aflatoxin B1 biodegraded products by culture supernatant of Cladosporium uredinicola. ScienceAsia 2020, 46, 308. [CrossRef]

121. European Commission. Commission Regulation (EC) No 386/2009 of 12 May 2009 amending Regulation (EC) No $1831 / 2003$ of the European Parliament and of the Council as regards the establishment of a new functional group of feed additives. Off. J. Eur. Union 2009, 52, 66-67.

122. European Commission. Commission Regulation (EU) 2015/786 of 19 May 2015 defining acceptability criteria for detoxification processes applied to products intended for animal feed as provided for in Directive 2002/32/EC of the European Parliament and of the Council. Off. J. Eur. Union 2015, 58, 10-14. 
123. European Commission. Commission Implementing Regulation (EU) 2017/913 of 29 May 2017 concerning the authorisation of a preparation of fumonisin esterase produced by Komagataella pastoris (DSM 26643) as a feed additive for all avian species. Off. J. Eur. Union 2017, 60, 33-35.

124. Vandamme, P. Taxonomy of the genus Cupriavidus: A tale of lost and found. Int. J. Syst. Evol. Microbiol. 2004, 54, 2285-2289. [CrossRef]

125. Xu, X.-W.; Huo, Y.-Y.; Wang, C.-S.; Oren, A.; Cui, H.-L.; Vedler, E.; Wu, M. Pelagibacterium halotolerans gen. nov., sp. nov. and Pelagibacterium luteolum sp. nov., novel members of the family Hyphomicrobiaceae. Int. J. Syst. Evol. Microbiol. 2011, 61, 1817-1822. [CrossRef]

126. Yoon, J.-H.; Kang, S.-J.; Park, S.; Oh, T.-K. Devosia insulae sp. nov., isolated from soil, and emended description of the genus Devosia. Int. J. Syst. Evol. Microbiol. 2007, 57, 1310-1314. [CrossRef]

127. Huang, C. Extensively drug-resistant Alcaligenes faecalis infection. BMC Infect. Dis. 2020, 20, 1-11. [CrossRef]

128. García-González, T.; Sáenz-Hidalgo, H.K.; Silva-Rojas, H.V.; Morales-Nieto, C.; Vancheva, T.; Koebnik, R.; Ávila-Quezada, G.D. Enterobacter cloacae, an emerging plant-pathogenic bacterium affecting chili pepper seedlings. Plant Pathol. J. 2018, 34, 1-10. [CrossRef]

129. Krzymińska, S.; Koczura, R.; Mokracka, J.; Puton, T.; Kaznowski, A. Isolates of the Enterobacter cloacae complex induce apoptosis of human intestinal epithelial cells. Microb. Pathog. 2010, 49, 83-89. [CrossRef] [PubMed]

130. Hirayama, T.; Miyazaki, T.; Ito, Y.; Wakayama, M.; Shibuya, K.; Yamashita, K.; Takazono, T.; Saijo, T.; Shimamura, S.; Yamamoto, K.; et al. Virulence assessment of six major pathogenic Candida species in the mouse model of invasive candidiasis caused by fungal translocation. Sci. Rep. 2020, 10, 1-10. [CrossRef]

131. Masood, M.I.; Qadir, M.I.; Shirazi, J.H.; Khan, I.U. Beneficial effects of lactic acid bacteria on human beings. Crit. Rev. Microbiol. 2010, 37, 91-98. [CrossRef]

132. El-Nezami, H.; Polychronaki, N.; Lee, Y.K.; Haskard, C.; Juvonen, R.; Salminen, S.; Mykkänen, H. Chemical moieties and interactions involved in the binding of zearalenone to the surface of Lactobacillus rhamnosus strains GG. J. Agric. Food Chem. 2004, 52, 4577-4581. [CrossRef] [PubMed]

133. Haskard, C.; Binnion, C.; Ahokas, J. Factors affecting the sequestration of aflatoxin by Lactobacillus rhamnosus strain GG. Chem. Biol. Interact. 2000, 128, 39-49. [CrossRef]

134. Niderkorn, V.; Morgavi, D.; Aboab, B.; Lemaire, M.; Boudra, H. Cell wall component and mycotoxin moieties involved in the binding of fumonisin B1 and B2 by lactic acid bacteria. J. Appl. Microbiol. 2009, 106, 977-985. [CrossRef]

135. Markowiak, P.; Śliżewska, K.; Nowak, A.; Chlebicz, A.; Żbikowski, A.; Pawłowski, K.; Szeleszczuk, P. Probiotic microorganisms detoxify ochratoxin A in both a chicken liver cell line and chickens. J. Sci. Food Agric. 2019, 99, 4309-4318. [CrossRef] [PubMed]

136. Kankaanpää, P.; Tuomola, E.; El-Nezami, H.; Ahokas, J.; Salminen, S.J. Binding of aflatoxin B1 alters the adhesion properties of Lactobacillus rhamnosus strain GG in a Caco-2 model. J. Food Prot. 2000, 63, 412-414. [CrossRef]

137. Mastanjević, K.; Lukinac, J.; Jukić, M.; Šarkanj, B.; Krstanović, V.; Mastanjević, K. Multi-(myco)toxins in malting and brewing by-products. Toxins 2019, 11, 30. [CrossRef] [PubMed]

138. Ortiz-Villeda, B.; Lobos, O.; Aguilar-Zuniga, K.; Carrasco-Sánchez, V. Ochratoxins in wines: A review of their occurrence in the last decade, toxicity, and exposure risk in humans. Toxins 2021, 13, 478. [CrossRef]

139. Petruzzi, L.; Corbo, M.R.; Sinigaglia, M.; Bevilacqua, A. Yeast cells as adsorbing tools to remove ochratoxin A in a model wine. Int. J. Food Sci. Technol. 2014, 49, 936-940. [CrossRef]

140. Cecchini, F.; Morassut, M.; Moruno, E.G.; Di Stefano, R. Influence of yeast strain on ochratoxin A content during fermentation of white and red must. Food Microbiol. 2006, 23, 411-417. [CrossRef]

141. Freire, L.; Braga, P.A.; Furtado, M.M.; Delafiori, J.; Dias-Audibert, F.L.; Pereira, G.E.; Reyes, F.G.; Catharino, R.R.; Sant'Ana, A.S. From grape to wine: Fate of ochratoxin A during red, rose, and white winemaking process and the presence of ochratoxin derivatives in the final products. Food Control. 2020, 113, 107167. [CrossRef]

142. Caridi, A. New perspectives in safety and quality enhancement of wine through selection of yeasts based on the parietal adsorption activity. Int. J. Food Microbiol. 2007, 120, 167-172. [CrossRef] [PubMed]

143. Petruzzi, L.; Bevilacqua, A.; Baiano, A.; Beneduce, L.; Corbo, M.R.; Sinigaglia, M. Study of Saccharomyces cerevisiae W13 as a functional starter for the removal of ochratoxin A. Food Control. 2014, 35, 373-377. [CrossRef]

144. Huwig, A.; Freimund, S.; Käppeli, O.; Dutler, H. Mycotoxin detoxication of animal feed by different adsorbents. Toxicol. Lett. 2001, 122, 179-188. [CrossRef]

145. Joanis-Cassan, C.; Tozlovanu, M.; Hadjeba-Medjdoub, K.; Ballet, N.; Pfohl-Leszkowicz, A. Binding of zearalenone, aflatoxin B1, and ochratoxin A by yeast-based products: A method for quantification of adsorption performance. J. Food Prot. 2011, 74, 1175-1185. [CrossRef] [PubMed]

146. Yiannikouris, A.; François, J.M.; Poughon, L.; Dussap, C.-G.; Bertin, G.; Jeminet, G.; Jouany, J.-P. Adsorption of zearalenone by $\beta$-d-glucans in the Saccharomyces cerevisiae Cell Wall. J. Food Prot. 2004, 67, 1195-1200. [CrossRef]

147. Yiannikouris, A.; François, J.M.; Poughon, L.; Dussap, C.-G.; Jeminet, G.; Bertin, G.; Jouany, J.-P. Influence of pH on complexing of model $\beta$-d-glucans with zearalenone. J. Food Prot. 2004, 67, 2741-2746. [CrossRef] [PubMed]

148. Raju, M.; Devegowda, G. Influence of esterified-glucomannan on performance and organ morphology, serum biochemistry and haematology in broilers exposed to individual and combined mycotoxicosis (aflatoxin, ochratoxin and T-2 toxin). Br. Poult. Sci. 2000, 41, 640-650. [CrossRef] 
149. Vartiainen, S.; Yiannikouris, A.; Apajalahti, J.; A Moran, A.C. Comprehensive evaluation of the efficiency of yeast cell wall extract to adsorb ochratoxin A and mitigate accumulation of the toxin in broiler chickens. Toxins 2020, 12, 37. [CrossRef]

150. Ejiofor, T.; Mgbeahuruike, A.C.; Ojiako, C.; Ushie, A.M.; Nwoko, E.I.; Onoja, I.R.; Dada, T.; Mwanza, M.; Karlsson, M. Saccharomyces cerevisiae, bentonite, and kaolin as adsorbents for reducing the adverse impacts of mycotoxin contaminated feed on broiler histopathology and hemato-biochemical changes. Vet. World 2021, 14, 23-32. [CrossRef] 